Kristensen, Tenna R. (red.). Haderslev - en købstad bliver til.

Udgravninger ved Starup og Mølleåen . . . . . . . . . . . . . . .

Hauptwerk Haus Lensnack.

Mehlhorn, Dieter-J.: Architektur in Schleswig-Holstein.

Vom Mittelalter bis zur Gegenwart . . . . . . . . . . . . . .

Nielsen, Ditlev: Som jeg så det - sønderjyske erindringer $\ldots . . . .$.

Hansen, J.K.: Fra husmandssøn til Rigets Borg. . . . . . . . . . . . . . . . 238

Rasmussen, Carsten Porskrog, René Rasmussen og Axel Johnsen (red.):

Sønderborg soldater. Kasernen i Sønderborg 1907-2014 . . . . . . . . . . . . 240

Rheinheimer, Martin: Ipke und Angens. Die Welt eines nordsfriesischen

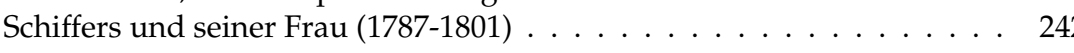

Riecken, Claas: Berthold Bahnsen Friesisch-schleswigscher Landtagsmann 244

Sørensen, H. E.: Alle de skjalde. Litteraturen i Sønderjylland og Sønder-

jylland i litteraturen $\ldots \ldots \ldots \ldots \ldots . . . \ldots \ldots$

Forfatterliste

Arkiver, museer og forskningsinstitutioner 2015 . . . . . . . . . . . . .

Fra den lokalhistoriske arbejdsmark i Sønderjylland 2015 . . . . . . . . .

Oversigt over årsskrifter og periodica $2015 / 2016$. . . . . . . . . . . . .

Historisk Samfund for Sønderjylland

\section{Skibsreder Jacob Bendixen fra Stolliggård}

\section{En Aabenraa-matadors storhed og fald}

\section{Af MikKel Leth Jespersen}

Gennem et langt liv som kaptajn og skibsreder opbyggede Jacob Bendixen et af det danske monarkis største rederier. Han var blandt de første danske kaptajner, der sejlede på Rio de Janeiro i 1820'erne, hvorefter han gik i land på sin hjemegn og fik bygget det ene store skib efter det andet. Samtidige iagttagere beskriver ham som en sympatisk mand, der vandt folk for sig, hvor han kom frem i det ellers forholdsvis barske søfartsmiljø. Han var svoger til alle tiders største Aabenraa-matador, Jørgen Bruhn, som han livet igennem stod i et tæet forretningsmæssigt og personligt forhold til. I 1858 døde Jørgen Bruhn, og ved samme tid tog det kun Jacob Bendixen nogle få fejlslagne investeringer at sætte sit store rederi over styr med omfattende konsekvenser for hele familien til følge.

\section{Indledning}

Både Jacob Bendixens og Jørgen Bruhns roller i opbygningen af den oversøiske Aabenraa-søfart er beskrevet i min bog Kaptajner og kolonier. Sejlskibstidens oversøiske Aabenraa-søfart (1820-1890), men mens Jørgen Bruhn er biograferet i flere omgange, foreligger der endnu ingen samlet skildring af Jacob Bendixens levnedsforløb. ${ }^{1}$ Det er derfor hensigten med denne artikel at tegne et billede af Jacob Bendixens familiære baggrund, karriere til søs, opbygningen af hans rederi, hans netværk af familie og venner på Aabenraa-egnen og til sidst rederiets endeligt og konsekvenserne heraf for familien. Da han var en af de centrale aktører i opbygningen af Sønderjyllands oversøiske søfart i 1800-tallet, bidrager Jacob Bendixens personlige historie med væsentlige aspekter til dette vigtige kapitel i den sønderjyske erhvervshistorie. Det gælder både beskrivelsen af selve sejladsen ude på verdenshavene og forståelsen af udgangspunktet hjemme på Aabenraa-egnen. Samtidig åbner historien om Jacob Bendixen for et stort persongalleri af mennesker, hvis liv på forskellig vis blev formet af deres relation til søfarten.

Artiklen bygger på et meget forskelligartet kildemateriale, da Jacob Bendixens aktiviteter dels kan spores i de statslige konsulatsrapporter fra den oversøiske søfart, dels kan følges i mere lokale kilder som avis- 
artikler, folketællinger, kirkebøger, grundbøger og erindringer fra personer, der kendte ham. Den mest omfattende beskrivelse af Jacob Bendixen i samtidige erindringer findes hos hans nevø, kaptajn Hans Bruhn. Derudover har et af hans børnebørn, Marie Bendixen, beskrevet Jacob Bendixen i sine erindringer. Samlet set gør dette omfattende kildemateriale det muligt at give en detaljeret beskrivelse af en bemærkelsesværdig personhistorie, som tager sin begyndelse på Løjt i slutningen af 1700-tallet.

\section{Baggrund og opvækst}

Allerede i 1700-tallet blev det karakteristisk for Aabenraa-søfarten, at selvom skibene var indregistreret i selve købstaden, så spillede byens nordlige opland - halvøen Løjt Land - en stor rolle i byens søfart. På Løjt boede en del af skibenes redere, ligesom området fostrede et voksende antal af skibenes kaptajner, styrmænd og menige besætningsmedlemmer. ${ }^{2}$ I landsbyen Stollig på Løjt Land fødte Clara Bendixen (1752-1811) den 18. februar 1788 sønnen Jacob Bendixen. Hendes ægtemand, som var drengens fader, hed Jep Bendixen (ca. 1741-1820). Han var en af den bakkede halvøs mange kaptajner og ud af den vidt forgrenede kaptajns- og rederslægt, som er blevet kaldt Bruhn-Bendixen-klanen. Medlemmerne af slægterne Bruhn og Bendixen var ikke blot gift ind i hinanden, men havde også nære relationer til en række af Løjt Lands andre kaptajnsfamilier. De ejede parter i hinandens skibe, som ofte var bemandet med flere af klanens medlemmer. ${ }^{3}$ Da Jacob kom til verden, havde Clara og Jep Bendixen allerede den seks år gamle søn, Jørgen.

Jep Bendixen havde taget borgerskab i Aabenraa som skipper i 1765, men trak sig på et tidspunkt tilbage som landmand og rentier på sin ejendom (et såkaldt toftbolsted) på Løjt. Clara var rundet af samme maritime miljø, da hun var datter af kaptajnsfamilien Rolfsen. ${ }^{4}$ Ifølge en skatteopkrævning i 1789 tilhørte parret Løjt Lands økonomiske elite. ${ }^{5}$ Jacob Bendixen voksede til, og med en slægtsbaggrund som hans kan det næppe undre, at han valgte at stikke til søs, da muligheden bød sig. Hans ældre broder, Jørgen, var også sømand. Han optræder i folketæl-

"Rolle", det vil sige mandskabsliste, over skibet Fortuna på 61 læster fra 1805. Øverst > står kaptajn Eschel Kier, og det fremgår, at han er født $i$ Aabenraa amt, og at han blev borger $i$ staden den 3. april 1782. Derefter følger styrmand Ludolf Conrad Bruhn, bådsmand Jesper Petersen og tømmermand Niels Paulsen. Næste mand på listen er skibets eneste matros, Jacob Bendixen. Rigsarkivet Aabenraa.

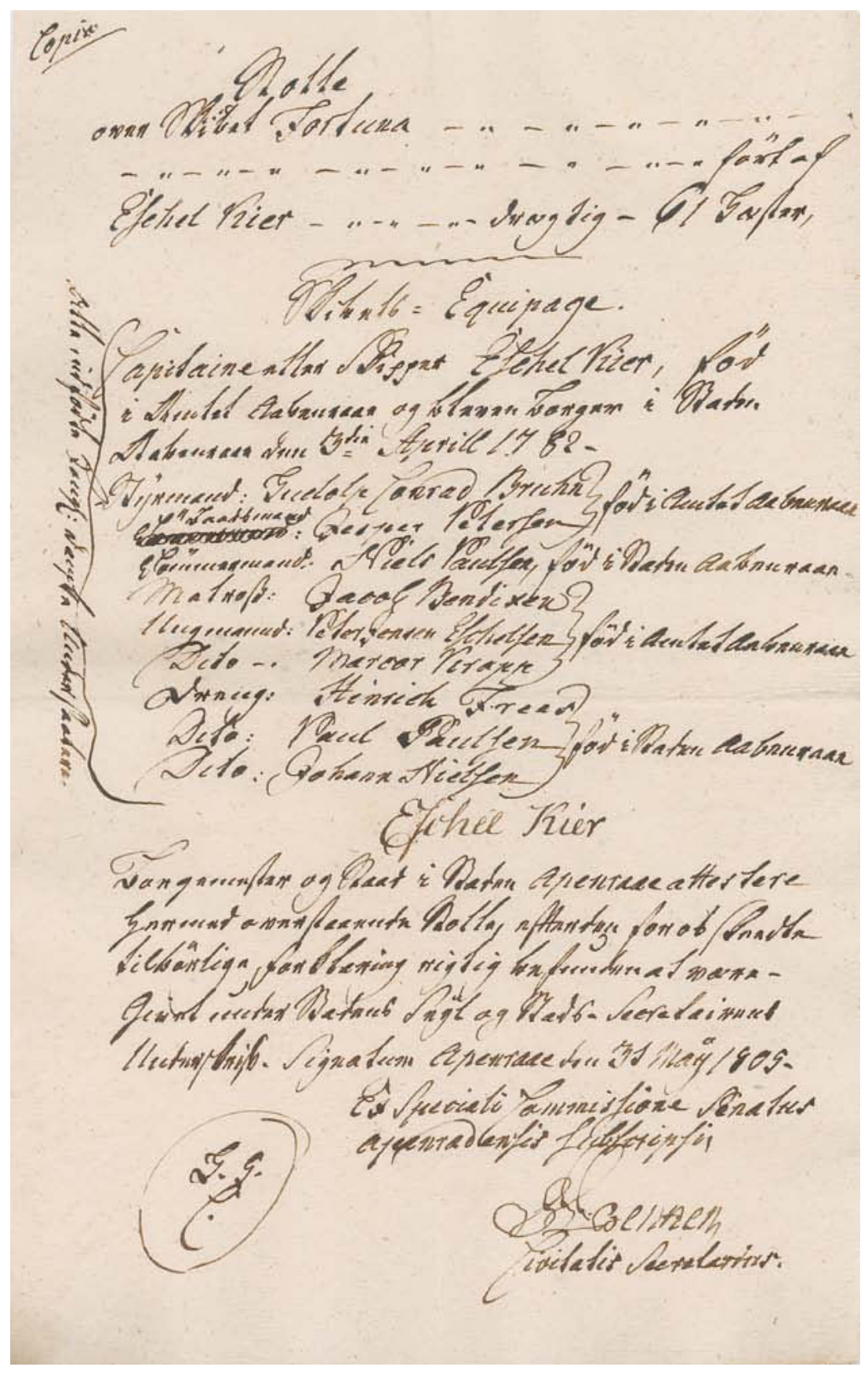


lingen i 1803, som 21 år gammel styrmand, men derefter forsvinder han ud af kilderne og er formentlig omkommet til søs. Udover Jørgen og Jacob fik ægteparret også de to sønner Nis (f. 1791) og Boy (f. 1792), der begge blev kaptajner, og - som det senere vil fremgå - fik også de deres navne indskrevet i Sønderjyllands søfartshistorie.

Aabenraa-avisen Freja fortalte i 1863, at Jacob Bendixen kom "allerede i en meget tidlig Ungdom tilsøes". Der findes dog ingen samtidige kilder, der belyser Jacob Bendixens tid som skibsdreng, men derfra avancerede man som regel til såkaldt jungmand og fra denne position videre til matros. I 1805, da Jacob Bendixen var fyldt sit syttende år, optræder han som matros på brigantinen FoRTUNA af Aabenraa. Skibet var ejet af Magnus Fischer i Aabenraa og blev ført af kaptajn Eschel Kier fra Løjt Skovby. Styrmand om bord var Jacob Bendixens senere svoger, Conrad Ludolph Bruhn (f. 1792), der dog vistnok døde til søs omkring den tid, da Jacob Bendixen blev gift med hans søster i $1813 .{ }^{6}$ Kredsen af personer omkring skibet var således lokale folk, der kendte hinanden, som det var almindeligt på Aabenraa-egnen. Det var vigtigt, at besætningsmedlemmerne kunne stole på hinanden, når skibene var på langfart, og det forholdt sig formentlig således, at jo større en andel af lokale folk, der var om bord på et skib, desto stærkere følte besætningsmedlemmerne sig forpligtet over for hinanden. De fleste regnede vel med en dag at vende hjem for at bosætte sig på Løjt, og så var det vigtigt, at man havde optrådt ordentligt, da man var ude at sejle.

Skulle Jacob Bendixen tage næste skridt på karrierestigen, måtte han have dokumenteret sine teoretiske styrmandskundskaber, så den 7 . februar 1805 tog han navigationseksamen i Tønning i det sydvestlige

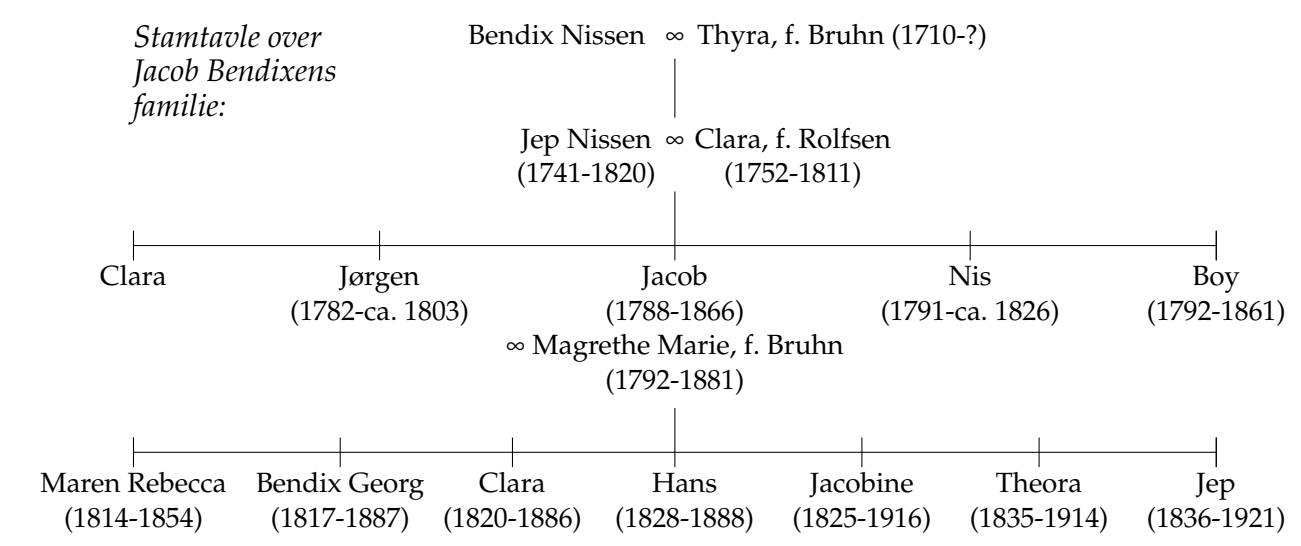

Slesvig. ${ }^{7}$ Det normale forløb var, at søfolkene fra Aabenraa og Løjt læste hos en lokal underviser, der selv havde erfaring udi styrmandskunsten, hvorefter de tog til København eller Tønning og aflagde selve prøven. Ifølge nevøen Hans Bruhns erindringer var Jacob Bendixen "en meget duelig Skibsfører". Det er dog uvist, hvilke skibe han sejlede med i sine første år som styrmand.

\section{Englandskrigene}

I anden halvdel af 1700-tallet havde Aabenraa-skibene specialiseret sig i fragtruten mellem Østersøen og Middelhavet. Denne sejlads var baseret på den danske neutralitetspolitik og Danmarks traktater med de muslimske bystater langs Middelhavets sydkyst. Den danske orlogsflåde var et vigtigt element i denne ordning, så da briterne bortførte hovedparten af den danske flåde i 1807, blev det meget vanskeligt for Aabenraa-skibene at forsætte deres hidtidige europæiske langfart. Straks ved krigsudbruddet tog englænderne ni store Aabenraa-skibe, og efter krigens afslutning blev det samlede tab opgjort til 46 af byens 66 store fragtskibe. ${ }^{8}$ Hvad Jacob Bendixen foretog sig, da krigen brød ud, er uvist, men intet tyder på, at han blev interneret af englænderne ligesom mange andre Aabenraa-søfolk. Ifølge et udsagn fra redaktør Frederik Fischer i tiden omkring 1840 gjorde Jacob Bendixen tjeneste om bord på rangskibet PRINDS CHRISTIAN under "den tapre Jessen" i $1808 .{ }^{9}$ Det skib, der her er tale om, kan kun være linjeskibet PRINDS Christian FrederiK, som blev ført af kaptajn Carl Wilhelm Jessen under søslaget ved Sjællands Odde den 22. marts 1808, men var Jacob Bendixen virkelig om bord?

I efteråret 1807 var PRINDs CHRISTIAN FREDERIK det ene af to danske linjeskibe, som englænderne ikke havde taget, da de to skibe havde været på togt til Norge. Jessen havde overtaget kommandoen i november 1807, så hvis Jacob Bendixen var blandt besætningen, kan det kun være et meget begrænset tidsrum, der var tale om. Efter Jessen overtog kommandoen, sejlede PRINDs CHRISTIAN FREDERIK først patrulje, og efter årsskiftet gik turen til Norge med forsyninger til hæren. Den 22. marts udkæmpede skibet slaget ved Sjællands Odde mod to engelske linjeskibe og tre fregatter. Det blev et blodigt slag, som kostede danskerne 69 døde og 132 sårede, og Jessen måtte overgive sig. Dagen efter sprængte englænderne PrInds CHRISTIAN FrEDERIK i luften. ${ }^{10}$ Blandt militærhistorikere har der været stor interesse for skibet og dets sidste heroiske 
kamp mod overmagten. I anledning af 150-året for søslaget satte kommandørkaptajn H.F. Kiær sig for at rekonstruere den ellers tabte rulle for skibets bemanding. ${ }^{11}$ Blandt rullens 575 navne leder man forgæves efter Jacob Bendixen, og det er således lidet sandsynligt, at han kæmpede på Prinds Christian FrederiK under kaptajn Jessen. Det peger i samme retning, at skibet ikke omtales i den biografiske artikel, som avisen Freja trykte om Jacob Bendixen i 1863. Man kan således kun gisne om, hvad Frederik Fischer har ment med sit udsagn. Det mest oplagte er, at redaktøren faktisk troede, at Jacob Bendixen havde været om bord på skibet under Jessens kommando, men det er også muligt, at han brugte det kendte skib med dets ligeså kendte kaptajn som et billede på, at Jacob Bendixen havde kæmpet for Danmark under Englandskrigene.

Ved tabet af flåden var den danske regerings muligheder for at føre søkrig mod englænderne blevet stærkt reducerede. En af de måder, man fra dansk side forsøgte at svare igen på, var ved at indlede en kaperkrig, således at man fra mindre privatudrustede - men kongeligt privilegerede - kaperskibe forsøgte at opbringe engelske handelsskibe. Et eventuelt bytte blev delt mellem kongen og den enkelte kaperkaptajn og dennes investorer. Det hele var nøje reguleret og institutionaliseret med såkaldte priseretter, der sikrede lovligheden og den rette fordeling af prisen, dvs. byttet. Den 13. april 1809 var Jacob Bendixen blevet styrmand på kaperkutteren HyæNE af Helsingør, der havde Jørgen Bruhn som kaptajn. Med sine blot to kommercelæster (kmcl.) var det ikke noget stort skib. Det havde en 12-mand stor besætning og var armeret med to kanoner - såkaldte svingbasser, der sad på rælingen og kunne drejes i alle retninger. Efter at have opbragt et britisk handelsskib overlod Jørgen Bruhn den 19. juli HyæNE til Jacob Bendixen. ${ }^{12}$ Senere på året 1809 blev Jacob Bendixen ifølge den tidlige omtalte artikel i Freja "fører for en Galease fra Helsingør, der kort Tid efter blev opbragt af Englænderne". ${ }^{13}$ Denne oplysning har det ikke været mulig at bekræfte eller uddybe ved hjælp af andre kilder, og måske er der faktisk tale om kutteren HyænE.

Den 29. september 1809 tog Jacob Bendixen borgerskab i København, hvilket foregik i forbindelse med, at han blev optaget i byens skipperlav. Det skete på baggrund af hans ovennævnte styrmandseksamensbevis fra Tønning. Inden der var gået et år, havde Jacob Bendixen dog mistet sine personlige papirer som styrmand om bord på fregatskibet DANNEBRog på $245 \mathrm{kmcl}$. ført af kaptajn Jochum Herholdt fra Assens. Skibet var ejet af den københavnske grosserer Friedrich Tutein (1757-
1853). Den 22. marts udstedte kaptajnen et brev til sin tidligere styrmand, hvoraf det fremgår, at DANNEBRog var brændt op i søen den 12. marts, og at Bendixens papirer ved den lejlighed var gået tabt. ${ }^{14}$ Den 23. april 1810 udstedte magistraten i København et nyt borgerbrev til Jacob Bendixen, hvis ordlyd var lig det oprindelige dokument. Samme år fremgår det, at han havde logi i Nyhavn nr. 13. Derudover er lidet kendt om hans gøren og færden i disse år. I 1811 oplyses det dog, at han sejlede som styrmand fra Norge..$^{15}$

Snart foretog Jacob Bendixen en række dispositioner, der tyder på, at han ville vende hjem til Aabenraa-egnen, når han havde tjent penge nok til at kunne etablere sig. I 1813 giftede han sig med Margrethe Marie Bruhn (1792-1881), som var søster til vennen Jørgen Bruhn. Brylluppet stod den 6. juli og indledte et langt og efter alt at dømme lykkeligt ægteskab. Dermed var Bruhn-Bendixen-dynastiet blevet knyttet sammen ved endnu et giftermål. Jacob Bendixen blev nu svoger til de Bruhn-brødre, der - sammen med ham selv - skulle blive dominerende personer i Aabenraa-søfarten frem til udgangen af 1850 'erne. ${ }^{16}$ Senere samme år, den 7. august, overtog han en mindre landejendom (et toftbolsted) i landsbyen Stollig på Løjt Land, som indtil da var ejet af hans farbroder, skipper og reder Nis Bendixen (1743-1822).

Selvom Jacob Bendixen hermed havde etableret en base på sin hjemegn, var han fortsat borger i København. I 1814 blev han styrmand på det $98 \mathrm{kmcl}$. drægtige CATHARINA af København, som var ejet af skibsreder Peter Christian Knutzon. Om bord på dette skib sejlede han blandt andet på England og Frankrig. I 1816 avancerede Jacob Bendixen for første gang til kaptajn på det kun godt halvt så store skib BoLETTE \& MARIE af Nyborg på $53 \mathrm{kmcl} .{ }^{17}$ I 1820 opsagde Jacob Bendixen sit københavnske borgerskab, og den 21. marts blev han i stedet borger i Aabenraa. ${ }^{18}$ Flytningen var muligvis forårsaget af de dårlige tider i det københavnske handelsliv. Måske spillede det også en rolle, at Jacob Bendixens fader netop var død den 11. marts dette år. Blandt den hjemvendte kaptajns første initiativer var købet af BoLETTE \& MARIE sammen med Jørgen Bruhn. Nogle af pengene til anparterne i skibet skaffede Jacob Bendixen efter alt at dømme ved hjælp af to lån, som han optog i sin ejendom i Stollig i marts måned. Det ene til en gårdmand i Løjt Skovby ved navn Hans Kjær, det andet til skibskaptajn Johann Bahnsen Wohlgehagen i Aabenraa. ${ }^{19}$ Jacob Bendixen fortsatte selv som skibets kaptajn, og i de efterfølgende år sejlede han i pendulfart mellem Nord- og Sydeuropa. Ved købet af BoletTe \& MARIE lagde Jacob 
Bendixen på to måder grunden til sine aktiviteter i de følgende 40 år: For det første blev han nu parthaver i det skib, han selv førte. For det andet indledte han det nære forretningsmæssige partnerskab med Jørgen Bruhn, som blev vigtigt for hans aktiviteter mange år frem.

\section{Med kurs mod Sydamerika}

Da intet tyder på, at Jacob Bendixen havde været uden for europæiske farvande før midten af 1820 'erne, må han have tjent sine sporer i den europæiske fragtfart. I 1820'erne og 1830'erne kom han dog - ligesom en række andre kaptajner fra Aabenraa - til at sejle adskillige ture fra primært Hamborg til Sydamerika. Efter Englandskrigene orienterede rederne fra Aabenraa sig primært mod Hamborg, hvor deres skibe stadig oftere blev forsikrede og befragtede. I den store hansestad havde man blikket stift rettet mod Brasilien, hvis status som portugisisk koloni begyndte at smuldre fra 1808, og i 1821 var det endeligt forbi, da Brasilien blev udråbt til selvstændigt kejserrige under kejser Pedro 1. $\mathrm{Nu}$ var Brasilien blevet et åbent og attraktivt oversøisk marked for europæisk handel og søfart.

Fra dansk side fulgte man også denne udvikling nøje, da man håbede, at skibsfart på Sydamerika kunne bidrage til en genetablering af det danske monarkis stolte søfartstradition, som havde lidt et alvorligt knæk under Englandskrigene. I 1818 ankom den første danske chargé d'affaires, der samtidig skulle fungere som generalkonsul, til Rio de Janeiro. Fra samme år begyndte et stigende antal danske skibe at lægge til i Rio de Janeiros havn. Til at begynde med var det kun et par stykker om året, men i 1824 var antallet oppe på 27, heraf var syv skibe fra Aabenraa. Et af disse skibe var BolETte \& MARIE, som blev ført af kaptajn Jacob Bendixen..$^{20}$ Af dette års skibsliste fra det danske generalkonsulat i Rio de Janeiro fremgår det, at skibet ankom fra Porto den 6. august. I lasten havde det købmandsvarer og vin. Jacob Bendixen står ikke blot angivet som kaptajn, men også som korresponderende reder. Den 30. september afsejlede BoLETTE \& MARIE mod Vigo i det nordvestlige Spanien i ballast.

Et andet af de Aabenraa-skibe, der anløb havnen i Rio de Janeiro i 1824 var PeRLen, der havde Jacob Bendixens yngre broder Nis Bendixen om bord som styrmand. PerLen rundede herefter Kap Horn, og efter et års tid på den Sydamerikanske vestkyst sejlede skibet videre mod Manila med Nis Bendixen som kaptajn. Han blev syg og døde i Fjernøsten, og han fik således ikke nogen lang karriere i Aabenraasøfarten, men hans deltagelse i PERLENs dristige færd, slog alligevel hans navn fast i søfartshistorien. ${ }^{21}$

Tilbage til Jacob Bendixen, som efter hjemkomsten fra sin første oversøiske rejse solgte sine parter i BolEtTE \& MARIE til Jørgen Bruhn. Han skulle formentlig bruge penge til deres ambitiøse fællesprojekt: Det store nye fregatskib CREOLE, der skulle sejle kolonister og soldater over Atlanten for den brasilianske regering. Brasilien var et kæmpestort og meget tyndt befolket land, derfor ønskede regeringen at tiltrække europæiske - især driftige nordeuropæiske - immigranter, som kunne slå sig ned i landet og fremme dets erhvervsliv. Samtidig befandt Brasilien sig i en ustabil politisk situation både internt og i forhold til nabostaterne. Regeringen var derfor i færd med at opbygge en hær, som gerne skulle have et betydeligt indslag af europæiske soldater. Derfor havde den brasilianske kejser i 1823 udsendt agenter til Europa, der skulle hverve kolonister og soldater. En af dem var Georg Anton Schäffer, som

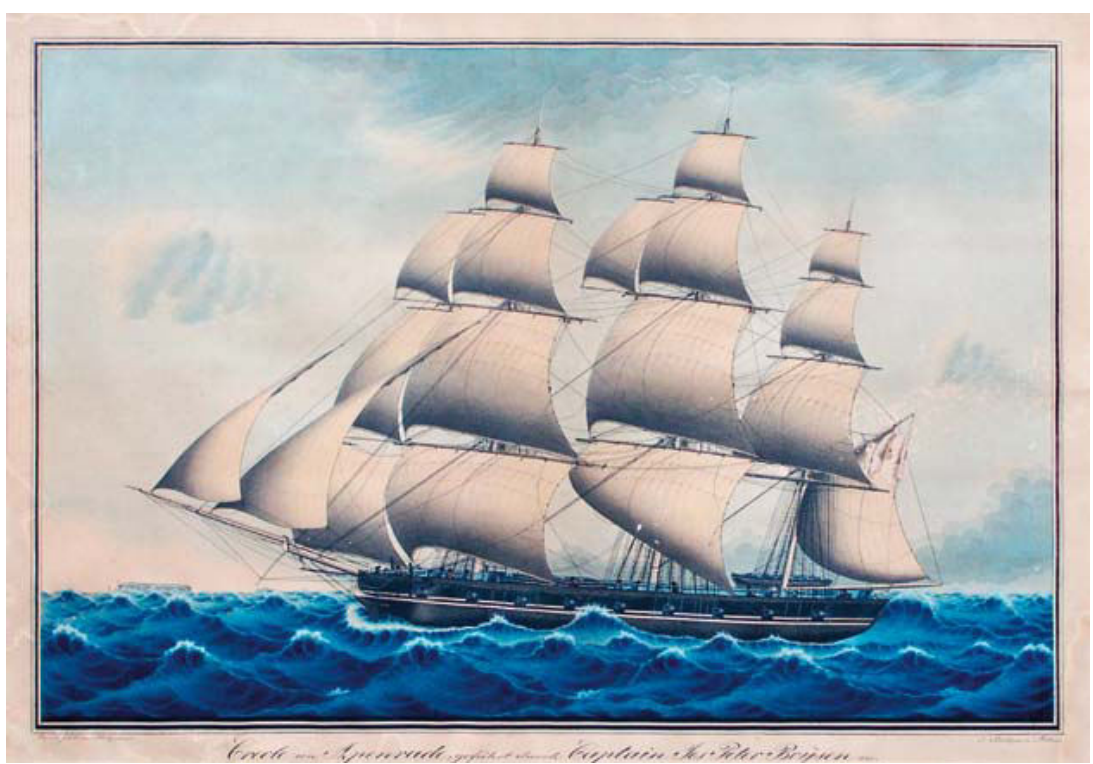

Der kendes adskillige skibsportrætter af CREOLE, men ingen fra Jacob Bendixens tid som kaptajn om bord på skibet. Mens han var kaptajn på CREOLE, var skibet det mest berømte og med sine 143 kommercelæster det største af alle Aabenraa-skibene. Dette skibsportræt stammer fra 1842, da Jes Peter Boysen var blevet kaptajn om bord. Museum Sønderjylland - Kulturhistorie Aabenraa. 
slog sig ned i Hamborg og udgav en omfattende skildring af kejserriget Brasilien. Der er tale om en flere hundrede sider lang beskrivelse af landets historie, samfundsforhold, handel, kultur mv. Dens næstsidste kapitel var viet til en immigrationsvejledning, der kunne tages i brug, når læseren var blevet overbevist om alle landets herligheder. ${ }^{22}$

Rejsen skulle foregå om bord på et kolonistskib, som blev ført af en dygtig kaptajn og var rigeligt forsynet med levnedsmidler og vand. Skibet ville kun være lastet med mennesker, og hvad der skulle bruges til at dække menneskelige behov. Det gjaldt en omhyggeligt udvalgt læge, nogle kirurger og et skibsapotek, der skulle afhjælpe nødstilfælde. Når kolonisterne ankom til Rio de Janeiro, ville de blive underholdt på den brasilianske regerings regning, indtil de så hurtigt som muligt kunne blive sendt ud til det sted, hvor de skulle slå sig ned. Schäffers bog var med andre ord en lang opfordring til læseren om at udvandre til Brasilien. Der findes ikke kildebelæg for, at Jørgen Bruhn og Jacob Bendixen var i kontakt med Schäffer, men det er sandsynligt, at deres kontakt til den brasilianske regering gik igennem ham, og at kontakten var etableret inden de satte gang $\mathrm{i}$ bygningen af CREOLE på Jacob Paulsens skibsværft i Aabenraa i 1824. ${ }^{23}$

Jørgen Bruhns søn, kaptajn Hans Bruhn (1813-1893), der selv var med på en af Jacob Bendixens rejser til Rio de Janeiro, fortæller i sine erindringer om udvandrerne. De fleste kom fra det indre Tyskland og måtte selv finansiere deres rejse, men når de så kom frem til Brasilien gav kejseren dem et stykke land, som de skulle opdyrke. Med soldaterne forholdt det sig lige omvendt. De fik betalt deres rejse og "gode håndpenge". Når de så havde tjent i kejserens hær i den aftalte periode, fik også de et stykke land, som de kunne bosætte sig på og opdyrke. Hans Bruhn hævder dog, at flere af dem gik en krank skæbne i møde, da de endte som straffefanger på Slangeøen. ${ }^{24}$

\section{Creole i Rio de Janeiro}

Jacob Bendixens rejser til Rio de Janeiro med CREOLE i anden halvdel af 1820'erne blev efter alt at dømme stærkt medvirkende til at etablere de tætte kontakter mellem Aabenraa og den brasilianske hovedstad, der skulle komme til at præge de følgende årtier. Det blev til fem overfarter med i alt omkring 2000 personer. På returrejsen medbragte skibet som regel kaffe eller sukker. Det betød, at turen var særdeles indbringende, da man havde gode fragter med begge veje. I 1830'erne ophørte persontransporten på udrejsen, og nu måtte Jacob Bendixen og Jørgen Bruhn finde andre laster til skibet.

Udover skibslisternes nøgterne konstatering af, at CREOLE befandt sig i Rio de Janeiros havn, er skibet også det hyppigst omtalte fartøj i de danske konsulatsrapporter fra denne tid. Nogle af omtalerne giver et forholdsvis detaljeret indblik i skibets sejlads. Den 6. januar 1829 rapporterede den nyudnævnte konsul Steen Bille, at han ved sin ankomst til Rio de Janeiro havde fundet to danske skibe i havnen. Det ene af dem var CREOLE, som var ankommet for over fem måneder siden. Det havde fået opsat sin hjemrejse på grund af manglende betaling fra den brasilianske regering. Nu havde problemet dog løst sig, og CREOLE ville afgå til Hamborg om seks dage med fuld ladning. ${ }^{25}$

Sidst på året var Jacob Bendixen og CREOLE atter i Rio de Janeiro, men denne gang var byen blot en trædesten på rejsen længere sydpå og videre rundt om Kap Horn. Den 27. september 1829 kunne Steen Bille fortælle, at CREOLE atter var ankommet, og at både kaptajnens og skibets gode egenskaber var velkendte i Rio de Janeiro. Man havde derfor opholdt en fragt til skibets ankomst. Nu var det sejlet videre mod Santos for der at komplettere sin ladning til Valparaiso. Creole var kendt som et smukt skib, og med på rejsen til Santos var guvernøren af Sao Paolo med hele hans familie. De fornemme passagerer var lidt af en æresbevisning til skibet fra Aabenraa. Ved ankomsten til Santos meddelte Jacob Bendixen Steen Bille i Rio de Janeiro, at der allerede havde været to andre Aabenraa-skibe i Santos dette år. Steen Bille tog dette som et udtryk for, at den lille by Aabenraa hævede sig ved nogle få driftige mænds aktiviteter. Kaptajnen havde anbefalet, at man indsatte en konsul i Santos - et synspunkt Steen Bille bakkede op. Der kom dog til at gå nogle år, før der blev indsat en dansk konsul i Santos. Under opholdet i Santos kom der mange fremmede om bord på CREOLE for at se det store flotte skib, og kaptajnen var en behagelig vært og selskabsmand, der indbød enhver, han mødte. ${ }^{26}$

Hans Bruhn fortæller desuden, at Jacob Bendixen blev gode venner med den brasilianske kejser Pedro 1. og derfor blev inviteret til middag på det kejserlige slot St. Christopher hver søndag, når CREOLE lå i Rio de Janeiros havn. ${ }^{27}$ Historien lyder utrolig, og mere sand er formentlig historien om, at Jacob Bendixen fik et landområde forærende af kejseren, som han aldrig tog i brug og derfor mistede retten til. I avisen Freja fortaltes mange år senere i anledning af Jacob Bendixens guldbryllup, at han gjorde sig "bemærket og yndet" hos den brasilianske kejser. Måske var der noget om snakken. Hans Bruhns fortæller også, hvorledes Jacob 
Bendixen købte en slave af sin ven tømrermester Rosantos. Slaven hed Emanuel og kom med hjem til Jørgen Bruhn på Løjt. Her boede han et års tid, indtil han faldt af hesten og druknede, da han badede hestene i Aabenraa Fjord. ${ }^{28}$ Denne historie kan bekræftes, da dødsfaldet er optegnet i Aabenraa Kirkebog, den 6. juni 1828. Hans Bruhn var ikke bare fuld af løgn, så måske er det også sandt, når han fortæller, at de sorte i Rio de Janeiro glædede sig, når de så Jacob Bendixen og råbte »Commandante de Navio CREOLE«, hvorefter kaptajnen gav dem nogle skillinger. ${ }^{29}$

Jacob Bendixen var en afholdt mand, hvilket Hans Bruhn var førstehåndsvidne til i sin tid som skibsdreng om bord på CREOLE. Kaptajnen var kendt for sin humane og menneskekærlige omgang med passagererne, og der kunne næppe findes nogen bedre mand til denne post end Jacob Bendixen. Det havde stor betydning om bord på skibet, da kaptajnen fungerede som myndighed på nær sagt alle livets områder; han viede unge par, døbte nyfødte børn - drengebørn blev ofte opkaldt efter ham - og afgjorde konflikter..$^{30}$ Officererne og soldaterne, som også var med om bord på CREOLE, forstod Jacob Bendixen ligeledes at omgås, selvom han næsten aldrig sagde et barsk ord til nogen. Hans Bruhn mener dog, at han kunne have været lidt skrappere over for mandskabet, hvilket førte til nogen uorden om bord, som ikke kom til kaptajnens kendskab. ${ }^{31}$ En anden af Hans Bruhns historier om Jacob Bendixen og hans rejser til Sydamerika handler om en rød ko, som kaptajnen skulle skaffe i Holsten til en engelsk købmand i Rio de Janeiro. Koen købte han hos Jørgen Bruhns svoger, som var præst i Borsfleth ved Glückstadt. Han tog den derefter med om bord på CREOLE. Her blev koen malket hver dag af kolonistpigerne, og den sørgede således for frisk mælk på rejsen. Dyret var åbenbart allerede med kalv, da skibet sejlede af sted, så nogen tid efter ankomsten til Rio de Janeiro fødte den en tyrekalv, som fik navnet Mister Dixon - opkaldt efter Jacob Bendixen. ${ }^{32}$

Med om bord på en af rejserne til Rio de Janeiro var ægteparret Kersting fra Hannover. Da manden betegnes som befalingsmand, var han formentlig en af de soldater, som CREOLE fragtede til Brasilien. ${ }^{33}$ Parret havde en søn ved navn Eduard Friedrich Christian Kersting, han var født i Celle den 11. april 1814. Drengen må have knyttet sig til Jacob Bendixen, da han blev om bord på CREOLE som skibsdreng, og kaptajnen blev en plejefar for ham. Eduard Kersting avancerede i 1831 til jungmand om bord og ifølge folketællingen i 1835 var han nu blevet styrmand. Da havde han fast bopæl hos familien Bendixen på Løjt. På optællingstidspunktet var han ganske vist fraværende til søs. Ifølge
Hans Bruhn blev Eduard Kersting konfirmeret i Løjt Kirkeby og var i det hele taget som en søn af huset. Han blev en dygtig kaptajn, der sejlede for rederiet Jacob Holms Sønner i København, Jørgen Bruhn og Wattenbach, Heilgers \& Co. i Calcutta. Endelig førte han skibet THERESA af Aabenraa, som han selv havde andel i. Efter at have solgt dette skib i Kina, slog han sig ned i Aubæk på Løjt. ${ }^{34}$ Senere flyttede han til Aabenraa, hvor han blev havnefoged. Eduard Kersting blev gift med en kaptajnsdatter fra Aabenraa-egnen, Maria Rebecca Richelsen - hun var niece til Jacob Bendixen og Margrethe Marie - og de fik fire børn. I 1857 tog han borgerskab i byen og blev senere udnævnt til havnefoged. ${ }^{35}$ Han døde i 1879, mens hustruen levede til 1903. ${ }^{36}$ Eduard Kersting blev opfattet som en rigtig Aabenraa-kaptajn, men hans vej til byen var altså gået over Jacob Bendixens sejlads med soldater og kolonister til Rio de Janeiro $i$ anden halvdel af 1820'erne.

Et andet interessant bekendtskab, som Jacob Bendixen gjorde på disse rejser, var den danske naturforsker Peter Wilhelm Lund (18011880), der på grund af tuberkulose var rejst til Brasilien på kurophold $i$ $1825 .{ }^{37}$ I 1829 returnerede han med en omfattende samling af brasilianske planter og dyr om bord på CREOLE. Han var ikke meget for at sejle, men mødet med Jacob Bendixen havde hjulpet ham til at udstå rejsen. Det fortæller han i et brev, som han skrev til kaptajnen efter sin hjemkomst. Jacob Bendixen skrev også til Lund, og fortalte om sin lykkelige hjemkomst til kone og børn, som han fandt sunde og raske. Måske har de to mænd diskuteret om Danmark var bedre end Brasilien eller omvendt, for Bendixen meddelte, hvorledes den skønne årstid nu var på vej med kommentaren "vores Land er dog bedre som Brasilien". Det var måske denne bemærkning, som fik Lund til at ønske Jacob Bendixen, at denne snart "kunne ombytte det ustadige Søliv ... med det rolige Landliv". Dermed indfangede han hele kaptajnens ambition, nemlig at tjene penge nok med sit skib til at etablere sig i land. Jacob Bendixen var dog i færd med at forberede endnu en rejse til Brasilien, så hvis Lund kendte nogen, der var interesserede $i$ at sejle med som passager, håbede han, at CREOLE ville blive anbefalet. ${ }^{38}$

\section{Familien på Stolliggård}

I 1832 kom så den dag, hvor Jacob Bendixen kunne bytte "det ustadige søliv med det rolige landliv", som P.W. Lund beskrev den overgang fra skibsfører til rentier, som alle succesrige kaptajner før eller siden 
gennemgik. Dette år foretog hans sin sidste rejse til Rio de Janeiro med CREOLE, og da han vendte hjem hen ved slutningen af året, slog han sig ned på Stolliggård, som han havde købt i 1829. Der var tale om en anseelig ejendom, som havde haft adelige privilegier i fjern fortid. Senere var jorden blevet delt, men gården var fortsat blandt Løjts største. Efter Jacob Bendixen havde overtaget ejendommen, flyttede han avlsbygningerne 200 meter mod nord. Her stod den ejendom, han allerede ejede, og som havde været hans barndomshjem, og den gjorde han til stuehus for det nye gårdanlæg. På husets gavle stod årstallet 1783 og initialerne J.B. og C.R. for hans forældre Jep Bendixen og Clara Rolfsen, som havde opført huset. ${ }^{39}$

Det fremgår af folketællingen fra 1835, hvem der dette år boede på gården, og hvor gamle de var. Øverst stod den da 47-årige kaptajn Jacob Bendixen selv og under ham hustruen Margaretha Marie Bruhn på 43. Derefter følger den betydelige børneflok, som parret nu havde hos sig af biologiske børn og plejebørn. Den ældste datter, Maren Rebecca, var dog allerede flyttet hjemmefra, da hun havde giftet sig med køb-

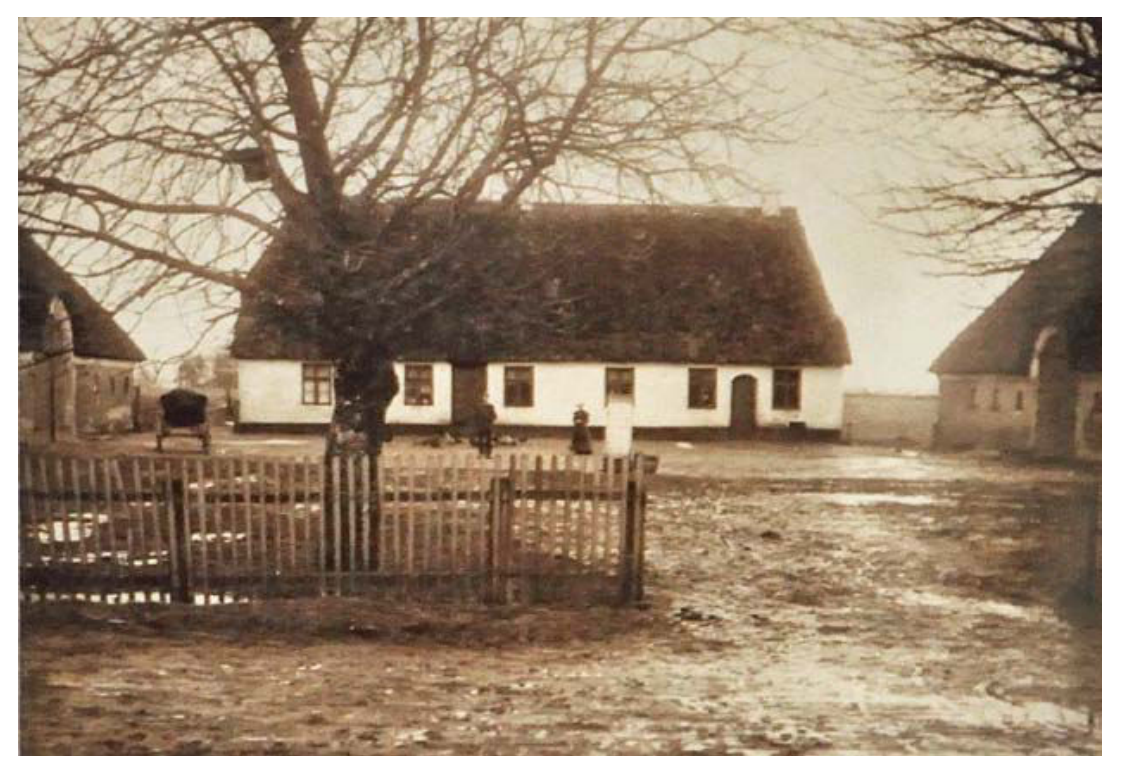

Ældre udateret fotografi af Jacob Bendixens gamle stuehus på Stolliggård. I siderne kan avlsbygningerne anes. I vinteren 1972 blev stuehuset revet ned, men en del af det fine interiør fra Jacob Bendixens tid kan i dag ses på søfartsmuseet $i$ Aabenraa. Museum Sønderjylland - Kulturhistorie Aabenraa. mand Hermann Davidsen i Aabenraa. Ældste hjemmeboende barn var sønnen Bendix Georg Bendixen på 18. Han var fraværende til søs som jungmand. Derefter fulgte de tre søstre Clara på 14, Botilla Sophia på 13 og Jacobine Maria på 9. Yngste barn i flokken var på dette tidspunkt Hans på syv. Hos familien boede nevøen/plejesønnen Andreas Johannes Schäfer (1821-1907) på 14. Hans biologiske forældre var Jacob Bendixens søster Clara og en løjtnant Venselin von Schäfer. Dette par var blevet gift den 10. december 1812 og havde fået Andreas Johannes den 3. maj 1821 i Løjt Kirkeby. Hvad der senere hen var blevet af ægteparret, er uvist. Endelig nævnes den 21-årige Eduard Kersting, som var ude at sejle. Derudover bestod husstanden af en barnepige, en tjenestepige og fire karle. Der var tale om i alt 15 personer.

Ti år senere ved folketællingen i 1845 var der sket en del ændringer i husstanden, som nu var vokset til 21 personer. Den første ændring var, at den nu 27-årige Bendix Georg var blevet gift med Caroline Amalie Frederikke Warner den 29. juli 1841. De to havde lært hinanden at kende, mens hun havde været guvernante på Høgebjerg hos hans morbroder kaptajn Hans Detlev Bruhn. Efter brylluppet var hun flyttet ind på Stolliggård. Ifølge ægteparrets datter, Marie, som mange år senere nedskrev sine erindringer, havde Caroline Warner tilbragt sine første syv leveår ved det kongelige hof, hvor hendes fader var kongens hofjægermester, og moderen var dronningens hofdame. Senere var familien kommet til Aabenraa, hvor hendes fader tilbragte sin alderdom og en broder tjente som skovrider. ${ }^{40}$ Ved tiden for ægteskabets indgåelse betegnes faderen, Jacob Peter Warner, som skovrider. Et indtryk af den opmærksomhed, der stod omkring Caroline Warner og Bendix Georg Bendixen i disse år, får man i Ellen Reuters breve til sin søfarende forlovede Andreas Matthiessen Schmidt. Den 28. juni 1841 fortæller hun, at man ventede kaptajn Bendix Bendixen til Hamborg, og at han derefter skulle hjem og giftes med "sin Line". ${ }^{41}$ Den 19. februar 1842 fortæller hun om brylluppet, og at kaptajnen havde så meget "Stads og Fias" med hjem, at alle talte om det. ${ }^{42}$ Bendix Georg Bendixen var nu kaptajn på sin faders store skibe, og hans ægteskab med Caroline Warner viste den medvind familien på Stolliggård havde i 1840'erne.

Blandt familiens tre ældste døtre var det kun den angiveligt sindssyge Clara, der endnu boede på gården i 1845. Botilla Sophia var død, mens Jacobine Maria var blevet gift og flyttet hjemmefra. Den 16-årige Hans boede endnu på gården, men var til søs som jungmand. Interessant er det, at Bendixen-parret i årene efter 1835-tællingen fik yderli- 
Det eneste bevarede fotografi af Jacob og Margrethe Marie Bendixen stammer formentlig fra deres guldbryllup i 1863, da de begge var godt oppe $i$ årene. Efter kopi på Museum Sønderjylland-Kulturhistorie Aabenraa.

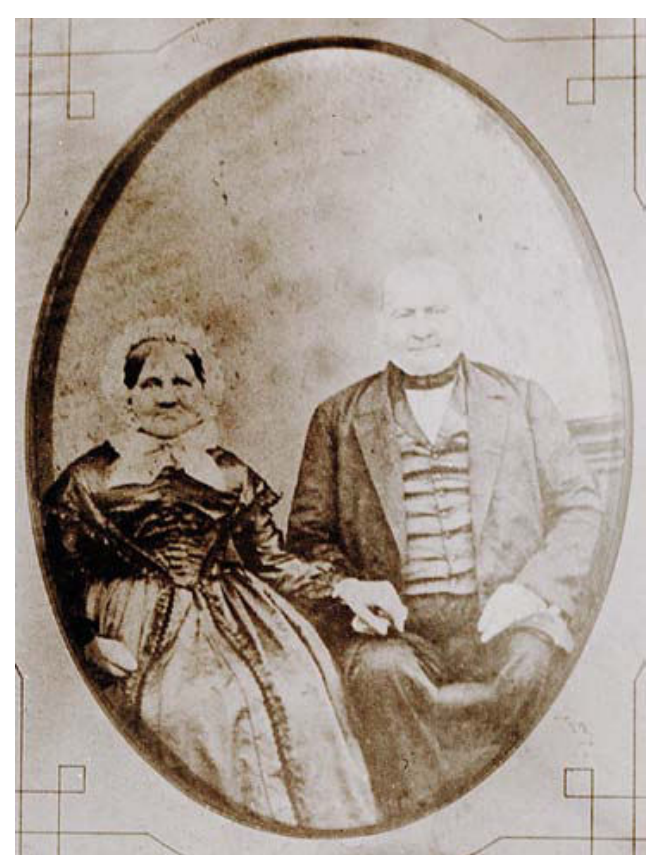

gere to børn, til trods for at de var henholdsvis omkring 45 og 50. Først fik de datteren Thora, som var ni år gammel i 1845 og nogle år senere Jep, som var fyldt seks. Eduard Kersting nævnes ikke længere på bopælen, men det gør til gengæld plejesønnen, Andreas Johannes Schäfer, der sejlede som styrmand og blev noteret som fraværende fra hjemmet. Udover familien boede der i 1845 en mængde tjenestefolk på Stolliggård. Det gjaldt en privatlærer, to husjomfruer, fem tjenestekarle og fire tjenestepiger, som alle var på kost. ${ }^{43}$ Antallet af tjenestefolk var således steget betydeligt.

Jacob og Margrethe Marie Bendixens hjem på Stolliggård blev et sted, hvor Bruhn-Bendixen-dynastiets mange medlemmer mødtes. Hans Bruhn fortæller, hvorledes der var et tæet forhold mellem Jacob Bendixen og Jørgen Bruhn: "Onkel og vores Fader stod stedse paa megen venskabelig Fod med hverandre, kom ogsaa undertiden en liden Kurre paa Traaden, saa græmmede de sig begge, indtil de blev syge, ingen vilde give efter, som det almindelig alle tiders er Tilfælde ved et saadan Uvenskab". Det var dog forholdet til søsteren, Margrethe Marie, som stod højest for Jørgen Bruhn. Hans Bruhn fortæller, at faderen aldrig foretog dispositioner som køb af ejendom eller skibsbyggerier, uden at han først havde drøftet sagen med hende: "Hendes Raad var ham et fuldstændigt Evangelium". Drøftelserne foregik som regel på Stolliggård, hvor Jørgen Bruhn jævnligt lagde vejen ind omkring. Det vigtigste møde foregik dog hver søndag morgen, hvor Bendixen-parret holdt "en Slags Børs", hvor familien kom fra nær og fjern og blev trakteret med ristet skinke. Omdrejningspunkt for selskabet var Jørgen Bruhn og hans søster, Margrethe Marie Bendixen.

Der blev formentlig også diskuteret politik omkring bordet på Stolliggård. Jacob Bendixen levede i den periode, hvor det nationale spørgsmål opstod og blev det dominerende tema på den politiske dagsorden i Slesvig. Omkring 1840 var de fleste af Aabenraas redere blevet tyskslesvig-holstensk-orienterede og modstandere af den danske helstat. Den samme tendens gjorde sig gældende på Løjt, hvor skibsrederne formentlig var påvirket af købstadens kaptajns-, reder- og storkøbmandsmiljø. Det gjaldt også Jacob Bendixen, der som kandidat til stændervalget i 1840 blev betegnet "overbevist slesvig-holstener". Dette var til den danske åndelige fører Frederik Fischers store fortrydelse. Han mente ikke, at denne betegnelse kunne gælde Jacob Bendixen. Det var i den forbindelse, at Frederik Fischer argumenterede med det formentlig forkerte forhold, at Jacob Bendixen havde kæmpet på PRINDs CHRISTIAN FrEDERIK under kaptajn Carl Wilhelm Jessen. Redaktøren tilføjede, hvad rigtigt var, at Jacob Bendixen efter den tid desuden havde sejlet under Dannebrog på verdenshavene. ${ }^{44}$

Jacob Bendixen var og blev dog orienteret mod det tyske. Han fik 52 stemmer ved stændervalget i 1840 og tilhørte den kreds af Aabenraaredere, der i 1842 skrev under på en petition, hvori de tilkendegav, at de ønskede skibsmærket "Dansk Eiendom" fjernet fra byens skibe og Dannebrog afskaffet til fordel for det slesvig-holstenske flag. ${ }^{45}$ De fleste personer i kredsen omkring Jacob Bendixen var også tyskorienterede. Det viser deres underskrifter på den hjemmetyske adresse fra Løjt 1849. Her genfindes hovedparten af de personer, der ejede parter i Jacob Bendixens skibe; svogeren Hans Detlev Bruhn til Høgebjerg, broderen Boy Bendixen, sønnen Bendix Georg Bendixen og svigersønnen Nis Hohlmann. ${ }^{46}$ Eneste undtagelse i familiekredsen var Jørgen Bruhn, der fastholdt en konservativ kongetro position uden dog at søge den nationale konfrontation. ${ }^{47}$ Jacob Bendixen og Jørgen Bruhn indtog forskellige positioner i den nationale konflikt, men at det skulle have ledt til større modsætninger imellem dem, hører man ikke om. 


\section{Rederiets storhedstid}

Selvom Stolliggård var en landbrugsbedrift, må det have været skibsredervirksomheden, der udfyldte Jacob Bendixens tid, efter han gik i land. Inden da havde han allerede været medreder for skibet BoLETTE \& MARIE, og han ejede fortsat andele i CREOLE. Nogle år efter sin landgang begyndte han dog at opbygge en flåde, der i slutningen af 1850'erne gav ham status af Aabenraas, ja faktisk hele hertugdømmet Slesvigs næststørste reder: "Næst det Bruhn'ske Bo eier her J. Bendixen 4 Skibe paa 9061/2 Clstr.", skrev avisen Freja den 1. juli 1858. De 906 1/2 kmcl. bekræftes af skibslisterne i Mercantil-Calender for det danske Monarchie for dette år. I slutningen af 1850'erne stod Jacob Bendixen som korresponderende reder for fire store langfartssejlere og var således blevet en af det danske monarkis allerstørste skibsredere. Han begyndte dog mere beskedent.

Det var i Sydamerika-fartens gode år, at Jacob Bendixen for alvor etablerede sig som skibsreder. Den første nybygning, han engagerede sig i efter landgangen i 1832, var fregatten CYBELE på 1041/2 kmcl., der blev bygget på Paulsens skibsværft i Aabenraa i 1836. Rederkredsen var identisk med CREOLES, hvilket vil sige, at den udover Jacob Bendixen selv bestod af brødrene Jørgen og Hans Detlef Bruhn. Kaptajn blev Erik Bock, som havde været Bendixens overstyrmand på CREOLE, og styrmand blev Johann Møller. Hans Bruhn fortæller, hvorledes CYBELE efter en indledende rejse mellem Danzig og New York sejlede "mange år i Brasilienfart". ${ }^{48}$ I skibslisterne kan man se, hvorledes skibet blandt andet sejlede salt til Rio de Janeiro og returnerede med kaffe til Europa.

I 1838 fik Jacob Bendixen bygget fregatten WodAN på 1161/2 kmcl. på Thorkild Andersens værft i Aabenraa. WodAN, der blev det skib, som Jacob Bendixen kom til at eje over den længste periode (ca. 23 år), blev også indsat i Sydamerika-farten. Det var det første skib, hvor Jacob Bendixen selv stod øverst på skibslisternes kreds af partredere. De resterende parter var ejet af svogeren Hans Detlef Bruhn og broderen Boy Bendixen. Sidstnævnte, som havde været kaptajn på nogle af Jørgen Bruhns største skibe, blev nu kaptajn om bord på Wodan. Det var en udbredt praksis blandt Aabenraa-rederne, at de optog skibenes kaptajner i rederkredsen med en mindre andel, så kaptajnen dermed fik egne økonomiske interesser i skibets indtjening. Jacob må have været tilfreds med Boys kommando på skibene, for broderen blev senere kaptajn på flere af hans andre langfartssejlere. Styrmand på WodAN blev
Jacob Bendixens ældste søn, Bendix Georg Bendixen (1817-1887). Han avancerede senere til kaptajn for skibet. Jacob Bendixen ejede WodAN indtil 1861, hvor det blev solgt i Amoy. ${ }^{49}$

I 1839, året efter bygningen af WoDAN, fremgår det af skibslisterne, at Jacob Bendixen var trådt ud af rederkredsen for CREOLE, men intet tyder på, at han sænkede ambitionsniveauet. I 1840 var han med i rederkredsen for to af Jørgen Bruhns nybygninger; fregatskibet HARPYE på $112 \mathrm{kmcl}$. fra Thorkild Andersens værft og den noget mindre brig COURIER på $701 \frac{1}{2} \mathrm{kmcl}$. fra Paulsens værft. Sidstnævnte beskrives af Hans Bruhn som "et smukt og velsejlende fartøj". ${ }^{50}$

At Jacob Bendixen havde ambitionerne intakt, viser bygningen af det $151 \mathrm{kmcl}$. store fregatskib NAPOLEON i 1841 på T. Andersens værft. De øvrige personer i rederkredsen var igen svogeren Hans Detlef Bruhn, broderen Boy Bendixen og endelig svigersønnen købmand Hermann Davidsen i Aabenraa. Endnu engang blev Boy Bendixen udnævnt til kaptajn på et af sin broders nybyggede skibe. I skibslisten for 1847 står Jacob Bendixen som enereder for NAPOLEON. Skibet blev til at begynde med indsat i Sydamerika-farten, men senere blev det et af de første Aabenraa-skibe, der sejlede på Hongkong, hvor det både blev registreret i konsulatsrapporterne for 1847 og 1848. Dermed blev Jacob Bendixen endnu engang en af de Aabenraa-redere, der var blandt de første til at indtage et nyt fragtmarked. Fra omkring $1850 \mathrm{og}$ frem til sejlskibstidens ophør var Fjernøsten Aabenraa-skibenes foretrukne farvand.

Udover skibets rolle som pionerskib er NAPOLEON også interessant, fordi det efter alt at dømme dannede forbillede for det kirkeskib, som Jacob Bendixen forærede Løjt Kirke den 24. maj 1845. Det hænger der endnu, og indlagt i kirkeskibet er tre dokumenter, hvoraf det ene oplyser, at det oprindeligt er lavet af styrmand Johannes Møller i Aubæk, at det var blevet restaureret og ophængt af kaptajn A.M. Christoffersen fra Løjt Kirkeby, og at skibet blev foræret til kirken af Jacob Bendixen i Stollig. ${ }^{51}$ Kirkeskibet fik navnet GLORIA DEO (til Guds ære), og man bad Gud om at opretholde sognets søfart og velsigne alle i Jesu navn. Kirkeskibet henviser ikke til NAPOLEON, men der er bemærkelsesværdige ligheder mellem de to handelsfregatter, som begge har ni kanonporte i hver side.

I 1849 fik Jacob Bendixen bygget fregatten Hindoo på 235 kmcl. på Paulsens værft. Det var angiveligt det sidste af rederens nybygninger, som blev en rigtig forretningsmæssig succes. Han ejede selv ni sekstendedele af skibet, mens de øvrige parter var fordelt, således at sviger- 


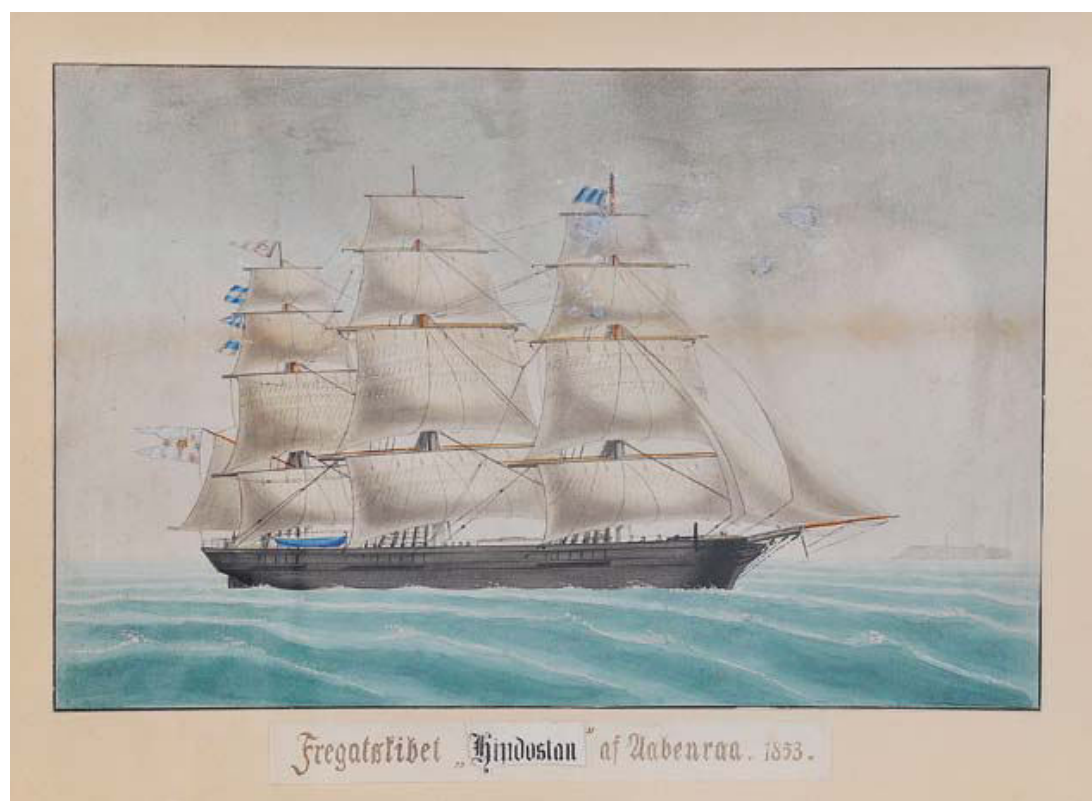

Akvarel af fregatskibet Hindostan, som blev Jacob Bendixens næstsidste nybygning. Det blev bygget $i 1853$ på Paulsen Værft i Aabenraa, og var det største skib, som hidtil var blevet bygget på havnen i Aabenraa. På skibsportrættet ses Helgoland i baggrunden til højre for HindOSTAN. Museum Sønderjylland - Kulturhistorie Aabenraa.

sønnen Nis Hohlmann (gift med datteren Jacobine) havde en fjerdedel, broderen Boy Bendixen en ottendedel og endelig havde en Peter Jespersen en sekstendedel. Kaptajner var sønnen Hans Bendixen (1828-1888) og svigersønnen Nis Hohlmann. ${ }^{52}$ Hindoo blev en udpræget langfartsejler, der i $1850^{\prime}$ erne fragtede varer mellem kontinenterne. Det kom forholdsvis ofte til Indien, fra hvis befolkning det også havde fået sit eksotiske navn.

Allerede i 1850 tog skibet den første tur fra Europa til Calcutta, hvor Hindoo ifølge den forholdsvis detaljerede skibsliste fra konsulatet ankom i april under kaptajn Nis Hohlmann. Hvad det bragte med fra London, fremgår ikke, men i den store bengalske havneby Calcutta blev det lastet med en bred vifte af kolonialvarer lige fra horn og skin, til forskellige farvestoffer, salpeter, ris, te, tobak, silke mv. Ifølge den fungerende konsul, J. Mackey, afsejlede skibet den 21. maj mod London. Den eneste ændring, der var sket i besætningen, var, at en sømand var fratrådt. I 1851 gik turen fra London til Hongkong og Whampoa og i 1852 til Singapore og Penang med stop på vejen i Calcutta på både ud- og hjemrejsen. Her afslører skibslisten igen, hvad Hindoo havde i lasten. Fra London til Calcutta - hvor det ankom den 30. maj-fragtede det købmandsvarer, vin, øl, jernbaneskinner og krudt. Fra Calcutta til Kina fragtede det hovedsageligt korn, men også sejlgarn, salpeter, ris og bomuld havde skibet i lasten. Fra Kina retur til Calcutta fragtede HINDOo blandt andet tin, kinesiske vaser og forskellige krydderier herunder safran, peber og muskatnødder. Om hele denne ladning blev losset i Calcutta er uvist, men her blev skibet lastet med flere eksotiske varer. I oktober afsejlede skibet HiNDoo mod London efter at have skiftet to af besætningsmedlemmerne ud. Under begge ophold i Calcutta noterede konsulen, at kaptajnen ikke havde meldt sin afrejse på konsulatet, som han skulle. ${ }^{53}$

I de følgende ti år sejlede Hindoo over hele kloden. Udover Europa og Fjernøsten var det også en tur over Stillehavet til den amerikanske vestkyst, fra San Francisco til Valparaiso og tilbage igen, ligesom det flere gange var i Australien. Til trods for at Hindoo havde været en indbringende investering, gik skibet ikke fri af de økonomiske vanskeligheder, der tårnede sig op for Jacob Bendixen fra slutningen af 1850'erne. Den 25. juni 1863 blev det ifølge Aabenraa-avisen Freja rapporteret fra Melbourne, at Hindoo efter en i øvrigt uproblematisk grundstødning var blevet solgt efter ordre fra admiralitetsretten, da der var blevet gjort fordringer gældende på $1.950 £$. Pengene kunne Jacob Bendixen åbenbart ikke udrede uden at sælge sit skib. ${ }^{54}$ Det har ikke været sjovt for den aldrende matador, at dette uheldige forløb blev omtalt i Aabenraas lokale avis.

\section{Nedgangstider}

De to sidste skibe, som Jacob Bendixen byggede, fik også navne med indisk klang. Det første var det allerede nævnte Hindostan på 259 kmcl. bygget på Paulsens værft i 1853. Navnets lighed med Hindoo var formentlig udtryk for et fromt ønske om, at Hindostan ville blive en lige så god forretning, når det satte kurs mod det indiske subkontinent. Jacob Bendixen ejede selv tre fjerdedele af skibet, mens sønnen Bendix Georg, der også blev dets kaptajn, ejede den sidste fjerdedel..$^{55}$ Bendix Georg førte Hindostan frem til 1857, hvor det blev overtaget af hans yngre broder Hans. Det sejlede over det meste af verden og blev registreret i havnebyer som Callao, Valparaiso, San Francisco, Ant- 
werpen, Calcutta og Melbourne. Hindostan er blevet beskrevet som et dårligt skib, der var en del af årsagen til rederens erhvervsmæssige nedtur i perioden omkring 1860. Ligesom WoDAN blev det også solgt i året 1861. Det foregik på auktion i Hamborg den 2. maj og indbragte Jacob Bendixen 45.500 Mark.

Det blev efter alt at dømme hans sidste og største nybygning, fregatten Himalaya, der blev Jacob Bendixens endelige ruin. Skibets navn signalerede ellers rederens store ambitioner. Denne store fregat var på hele 296 kmcl. og bygget på Paulsens værft i 1857. Til at begynde med gik det godt. Himalayas første og korte rejse gik fra Aabenraa den 3. juli 1857 til Danzig under den næstældste søn Hans Bendixens kommando. Førstestyrmand var Andreas Schäfer, der som tidligere nævnt var Jacob Bendixens nevø, der var vokset op som hans plejesøn. Sidst på efteråret 1857 sejlede det store skib af sted på sin første lange rejse. Det var nu blevet overtaget af Jacob Bendixens ældste søn, Bendix Georg Bendixen. I november måned 1857 mødte HimalayA det engelske skib MARY ANN NewETT, som var "i en meget beskadiget og hjælpeløs Tilstand". Det lykkedes kaptajnen og hans besætning at bringe det engelske skib ind til havnen i Pernambuco på den brasilianske kyst og derved redde både ladning og besætning. Den 3. april 1858 kunne man læse i Freja, at bedriften havde indbragt kaptajn Bendixen en smuk skibskikkert af mærket Throughton $\mathcal{E}$ Simms med en inskription, der fortalte om hans "hurtige og ædelmodige" bedrift. Himalaya sejlede derefter Jorden rundt. Først gik turen til Valparaiso, videre op langs den amerikanske vestkyst til San Francisco og derfra til Australien og Fjernøsten, hvorfra skibet vendte tilbage til Europa. Herefter sejlede det nogle ture mellem Europa og Fjernøsten.

Det fortælles, at det var dette skib, der "ødelagde ham", da det blandt andet var finansieret ved optagelsen af et lån på 11.200 rigsbankdaler, som skibet ikke tjente hjem. Skyld- og panteprotokollen for Stollig oplyser, at han fra 1857 og frem til 1861 optog en række lån i Stolliggård, som han ellers ikke havde belånt siden 1820. Det var formentlig vanskeligheder med at afdrage på den store gæld, der fik Jakob Bendixen til at sælge nogle af sine andre sejlskibe i 1861. I 1864 var Himalaya i Callao i Peru med købmandsvarer under Jacob Bendixens dattersøn kaptajn Poul Davidsen, som havde ført skibet de sidste par år. Herfra sejlede Himalaya mod Chincha Øerne i ballast for at hente guano. Omkring midten af 1860'erne blev skibet solgt til Norge og omdøbt til NoRDKAP. ${ }^{56}$ Dermed var det endegyldigt slut med Jacob Bendixens rederi.
Byggeriet af Himalaya havde været uheldig timing. Netop i 1857 indledte en verdensomspændende pengekrise en tid med dårlige konjunkturer for søfarten. På Aabenraas værfter blev skibene bygget på spekulation, det vil sige uden aftalt køber, og i 1859 lå der seks nybyggede skibe i havnen, hvoraf kun to var afsat. ${ }^{57}$ Det var altså på det helt forkerte tidspunkt, at Himalaya stod ud på verdenshavene med sin store tonnage, og det kan derfor ikke undre, at den aldrende reder og hans kaptajner (de to sønner Bendix Georg og Hans og senere dattersønnen Paul Davidsen) havde vanskeligt ved at forrente den store investering. Konsekvenserne blev dog først tydelige efter 1860.

\section{Bendix Georg Bendixens fald}

Jacob Bendixens ældste søn kaptajn Bendix Georg Bendixen var, som nævnt, kaptajn på flere af faderens store langfartsskibe. Bendix Georg og Caroline Bendixens datter, Marie, var født i 1852, og hun havde derfor sine tidligste barndomsminder fra tiden, hvor familien endnu levede i velstand. I sine erindringer fortæller hun, at hun elskede, når hun sammen med sin moder rejste til Flensborg eller Hamborg for at tage imod sin fader, når han anløb havnene med et af sine skibe. Han hyggede sig i familiens skød for en kort stund, inden han atter måtte af sted. Afskeden var smertelig, og om aftenen foldede moder og børn hænderne og bad Gud om at beskytte faderen. Fem gange sejlede han rundt om jorden, og hjembragte de smukkeste kinesiske ting; silke, kolonialvarer og et sybord med indlagt elfenben. I Bordeaux blev han optaget i frimurerlogen, fortæller hun.

Mens rederiet var på sit højeste, opførte Bendix Georg Bendixen et hus til sig selv og sin familie i Stollig. Familien kunne nu flytte ud fra Stolliggård og få deres eget. Hans Bruhn omtaler ejendommen som "det smukke lille Huus i Stollig", og Marie Bendixen kalder det "Unser schöner Besitz". Som mange andre kaptajner på Løjt havde Bendix Georg Bendixen investeret en del af sine opsparede penge i en kaptajnsgård, hvor han kunne trække sig tilbage, når han ikke længere sejlede på verdenshavene. Så vidt var han dog ikke kommet endnu, og netop mens han havde foretaget investeringen i det fine lille hus, begyndte det at gå ned ad bakke for familiens rederi. I 1856 lånte Bendix Georg 4.000 mark i Graasten Spare- og Lånekasse med sikkerhed i sin ejendom. To år senere lånte han sammen med sin far det samme beløb af en borger i Aabenraa til at udfri lånet. Denne manøvre gentog han i 1861, 
hvor han lånte pengene af sin svoger Nis Hohlmann på Valhalla. De 4.000 mark var formentlig blevet investeret i HimALAYA, og blev derfor næppe forrentet, og derfor kunne Bendix Georg ikke betale af på sit lån.

Rederiets nedtur ramte Bendix Georg Bendixen hårdt. Efterhånden som faderen solgte sine skibe, kunne han ikke længere få skib at føre og måtte gå i land. Det er ligefrem blevet hævdet, at han førte HimALAYA dårligt og derfor var en del af årsagen til faderens økonomiske deroute. ${ }^{58}$ Nogle kaldte ham "den uduelige". Det var han dog langt fra. De første mange år af sin kaptajnskarriere førte han faderens skibe WoDAN og HINDOSTAN - og det gjorde han nok ikke så dårligt, for det var i den periode, hvor rederiet klarede sig rigtig godt. At det så gik hurtigt ned ad bakke med HimALAYA fra slutningen af 1850'erne, kan vel næppe lægges på Bendix Georgs skuldre alene. Når man læser Hans Bruhn, som jo var Bendix Georgs fætter, får man en mere nuanceret beskrivelse af ham. Han hævder, at Bendix Georg Bendixen i sin tid var en af Aabenraas "raskeste kaptajner", men skæbnen var ham ikke god. Datteren Marie Bendixen fortæller, hvordan tilbagegangen ramte familien: Da hun var omkring 10 år gammel, gik det tilbage med famili-

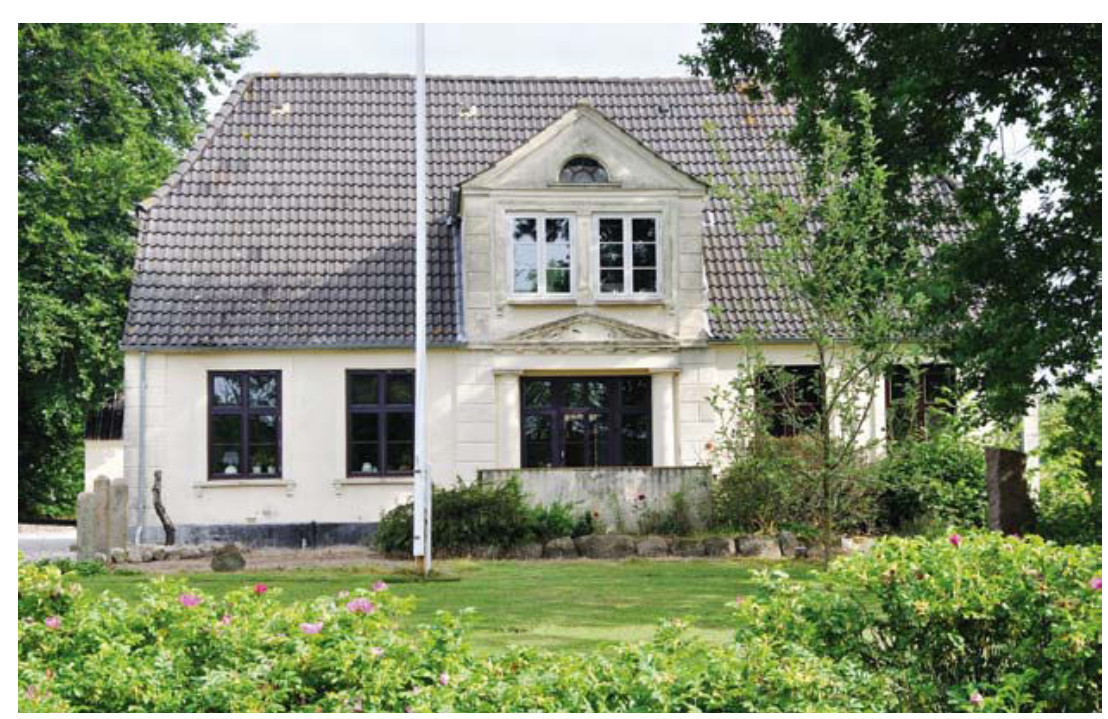

Det fine hus som Bendix Georg Bendixen fik bygget til sig og sin familie i Stollig. I dag har ejendommen adressen Stollig Bygade 2 og minder forbipasserende om, hoor usikker en metier søfarten kunne vare. Foto: Mikkel Leth Jespersen. ens økonomiske forhold. Det fine hus i Stollig måtte sælges og familien flyttede til Aabenraa.

Den anden af Jacob Bendixens sønner, der gjorde karriere som kaptajn på sin faders skibe, var Hans. Han førte blandt andet Himalaya og Hindostan. Senere blev han for en kort bemærkning kaptajn for rederiet Jørgen Bruhns Sønner, som var ejet af hans fætre. De havde skibet Helvetien, som Hans Bendixen i 1864 sejlede fra Cardiff til Manila med 504 tons kul. Her blev han dog afløst af skibets egentlige kaptajn, Eschel Boysen, der førte skibet tilbage til Europa. Om Hans Bendixen fik et nyt skib at føre er uvist, men i 1870'erne skrev fætteren Hans Bruhn, at Hans Bendixen endnu var skibsfører, "men Lykken har indtil Dato ikke været ham Huld". Til trods for hans position som kaptajn på nogle af Aabenraas største skibe, havde han ikke tjent penge nok til at kunne trække sig tilbage som velhavende rentier. Hans Bendixen var gift med Elise Paulsen, der ligesom ham selv var en del af BruhnBendixen-dynastiet. Hun var datter af Samuel Paulsen, som havde ægtet enken efter Jørgen Bruhns yngre broder Jacob Bruhn på gården Dalholdt, og han var dermed blevet optaget i slægtskredsen som en af deres egne. Da Hans Bruhn skrev sine erindringer, boede Hans og Elise i Stollig og havde fire børn. Efter rederiets lukning ernærede Hans Bendixen sig som krovært og købmand i Stollig.

Den 7. august 1863 blev Stolliggård, der nu var på 48,5 hektarer land, overtaget af familiens yngste søn Jep Bendixen. Det var dog en temmelig behæftet ejendom. I 1857 havde Jacob Bendixen, som nævnt, optaget tre store lån i Stolliggård, som var blevet fulgt af endnu et i 1860. Til trods for det dårlige udgangspunkt lykkedes det dog Jep at klare skærene. I 1864 blev han gift med Maren Rebecca Paulsen (1843-1916) fra Dalholdt, en søster til hans ovennævnte svigerinde Elise. Parret førte slægtsgården videre, men de nedarvede lån fik de aldrig indfriet, og frem til Jep Bendixens død i 1911 fortsatte belåningen af ejendommen. Jacob Bendixens dårlige økonomi i de sidste år af hans liv hang således ved familien på Stolliggård mange år frem.

\section{Guldbrylluppet 1863}

Netop i et af de år, hvor det gik hurtigt ned ad bakke for den gamle reder og dermed hele hans familie, kunne Jacob Bendixen og Margrethe Marie fejre et guldbryllup, som næppe har set sit lige på Løjt Land. Ægteparret var så populært blandt høj som lav, at folk stimlede til fra nær 
og fjern. Det fandt sted den 6. juli 1863 og er beskrevet i flere samtidige kilder. Den 4. juli, altså allerede et par dage inden selve guldbrylluppet, blev den store begivenhed omtalt i Aabenraa-avisen Freja med en yderst positiv skildring af det gamle ægtepar: I de mange år jubelparret havde været bosat i Stollig, havde alle agtet og æret dem for deres retskaffenhed, og den gæstfrihed, godhed og gavmildhed de altid havde udvist over for trængende sognebeboere. Derfor mente man på Frejas redaktion, at der ville være bred interesse for at høre noget om Jacob Bendixens liv til søs, og der fulgte derfor en længere skildring af hans karriere, som flere gange er blevet refereret i det foregående. Omtalen sluttede med en hjertelig lykønskning: "Den Fest som han nu efter et langt, Virksomt Liv staaer i Begreb med at feire, forskiønnes tillige med Nærværelsen af nogle af hans Børn og Børnebørn, hvoraf 3 ere Skibsførere. Til de mange Lykønskninger, der sikkert ville blive Jubelparret bragte fra Venner og Bekjendte føie vi vor med det Ønske, at de maae henleve Resten af deres Dage i Sundhed og Tilfredshed".

Om selve festen fortæller Hans Bruhn, som formentlig selv var til stede, at der ved den lejlighed havde forsamlet sig tusinder af mennesker i Stollig. Selv hvis man trækker lidt fra, må der have været tale om et usædvanligt stort opbud af mennesker, der kom for at vise det gamle ægtepar deres agtelse. Hans Bruhn fortæller videre, at det "gik meget lystigt og behageligt til ved den Højtidelighed, mange Foræringer, Gratulationer etc. indløb fra alle Kanter og er vel næppe noget Guldbryllup før eller sildiger blevet saa højtideligholdt, som dette, hvilket gav et slagende Beviis paa, hvor højagtede disse Oldinger stode ved Høje og Lave". Denne popularitet giver Marie Bendixen en forklaring på i sine erindringer: Da hun kom til søsterhuset i Christiansfeld den 1. oktober 1878, blev hun spurgt, om hun kendte søster Højsvig, der også kom fra Stollig, og hun blev straks ført hen til hende. Søster Højsvig fortalte $\mathrm{nu}$, at hendes forældre havde været daglejere på Stolliggård, og Jacob Bendixen havde ladet et lille hus bygge til de to gamle, hvor de kunne tilbringe deres gamle dage.

Marie fortæller videre, at festlighederne under guldbrylluppet i 1863 havde gjort et stort indtryk på hende - hun var da 11 år gammel. Mange af de kaptajner og skibsredere, som havde samarbejdet med Jacob Bendixen kom rejsende til fra nær og fjern. Da det var højsommer, blev den kirkelige fejring holdt i det fri. Et blæserorkester og et 46-piger stort kor modtog guldbrudeparret med sang og musik.

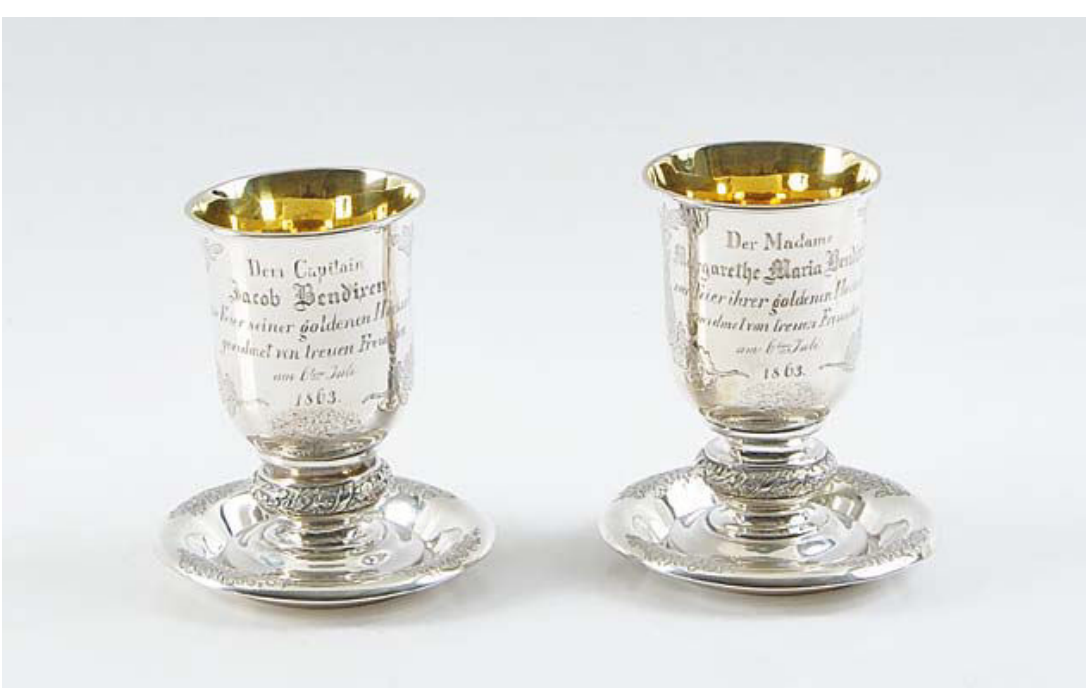

De to små sølvbxgere blev givet til Jacob Bendixen og Margrethe Marie Bendixen anledning af deres guldbryllup. Gaverne var købt for penge indsamlet på egnen. På den ene står: "Dem Capitain Jacob Bendixen zur Feier seiner goldenen Hochzeit gewidmet von treuen Freunden am 6ten Juli 1863“. Den anden indledes med "Der Madame Maria Margrethe ..." og derefter er resten af teksten den samme. Museum Sønderjylland - Kulturhistorie Aabenraa.

\section{Afslutningen}

Hans Bruhn fortæller, at Jacob Bendixen var "i mange Aar ja indtil 4-5 Aar førend sin Død en meget velhavende mand, efter min Mening vistnok over 100.000 Rdl. Courant, havde selv to store Skibe for egen Regning og desforuden flere andre Skibsparter sammen med Fader [Jørgen Bruhn], sin Gaard fri ext. men de sidste Aaringer ruinerede de 2 Skibe [Hindustan og Himalaya] ham aldeles, alting gik i mod, og gik hans store Formue bort til ingen ting, saa han maatte sælge sine værdifulde Skibe for Spotpris, for at gjøre sine Debitorer Ret og Skel, maatte belaste sin Gaard og overlade samme til sin yngste søn Jep Bendixen, tog Bolig i Aftægtshuset, hvor han levede i flere Aar, tilsyneladende munter og vel, men jeg er overtydet om, at disse Formuesforandringer trykkede de to Gamle mere end som nogen troede". Det var således, kredsen omkring Jacob Bendixen oplevede nedturen.

Det var dog ikke kun erhvervsmæssige nederlag, der plagede Jacob Bendixen på hans gamle dage, "han var ogsaa af og til plaget med Po- 
dagra og Gigt, var i sin Manddomsalder stærk og feed", skriver Hans Bruhn om sin aldrende onkel. Det lune gemyt synes dog ikke at have forladt ham, for han "spillede gerne et Parti Lhombre ..., han spillede ikke af Lidenskab, for at vinde Penge, men blot for at more sig og sine Gæster". Man kan levende forestille sig den selskabelige Jacob Bendixen holde humøret højt på trods af sin modgang.

Jacob Bendixen døde i 1866, 78 år gammel, og blev begravet på Løjt Kirkegård den 18. december, og det kan vel næppe undre nogen, at der også ved den lejlighed stillede et stort følge. Margrethe Marie overlevede ham med mange år og var rask og munter højt op i alderen. Efter Jacobs død flyttede hun ind hos Jep på Stolliggård, hvor hun boede til sin død den 13. januar 1881.

Både Jacob og Margrethe Marie nåede at opleve konsekvenserne af rederiets konkurs, men faldet blev langt fra så smerteligt for dem som for sønnen Bendix Georg og hans familie. Hos det førhen så feterede par blev den økonomiske nedtur fulgt af en social deroute, som splittede de to ægtefæller. Hans Bruhn fortæller, at Bendix Georg - udover at han måtte gå i land og sælge sit hus - havde problemer på hjemmefronten. Det var efter alt at dømme ikke nemt for den førhen så fornemme Caroline Bendixen at affinde sig med, at familien nu sad i små kår.

Tiden som kaptajn på nogle af Aabenraas største sejlskibe havde dog ikke givet Bendix Georg nykker. Han holdt sig ikke tilbage for at bruge sine kræfter på et "hvilket som helst arbejde", fortæller Hans Bruhn. Til at begynde med fik Bendix Georg arbejde som havnemester og lods, hvilket gav en god indtægt, fortæller datteren Marie. Senere måtte han dog opgive disse hverv og fik i stedet arbejde på et skibsværft i Aabenraa, som fortsat gav familien brød på bordet. Efterhånden gik det dog helt galt, da han kom i dårligt selskab og begyndte at drikke. Den tidligere så stolte skibskaptajn mistede selvrespekten, drak stadig mere og blev ludfattig. Marie skriver videre, at moderen var fortvivlelsen nær og lod af og til børnene alene til disses store bekymring.

Kronologien for dette forløb er uklar, men bådsmand Søren Møller fra Aabenraa fortæller, at han omkring 1873 arbejdede sammen med takkelmester Petersen fra Gildegade på Paulsens værft. De skulle udstyre den nybyggede skonnert CLARA med tovværk. Efter nogle dage skulle takkelmesteren bruge en mand til "og han fik en gammel kaptajn Bendixen som i flere Aar havde arbejdet sammen med ham". ${ }^{59}$ Der kan næppe være tale om andre end Bendix Georg Bendixen, der på dette tidspunkt var omkring 56 år gammel. Det var formentlig i løbet af 1870 'erne, at livet endegyldigt smuldrede for Bendix Georg, og den 27. oktober 1887 døde han ifølge kirkebogen som "forhenværende kaptajn" på arbejdshuset, det vil sige fattiggården, i Aabenraa. Han havde således ramt samfundets absolutte bund.

Mens Bendix Georg efterhånden havde mistet fodfæstet helt, var det lykkedes hans hustru at give børnene en nogenlunde anstændig opvækst, og de klarede sig alle hæderligt. Hun fik blandt andet midler til deres underhold ved at sælge ud af de værdigenstande, hun havde bevaret fra de gode år. Samtidig modtog hun understøttelse fra Aabenraa Sømandskasse, som Jørgen Bruhn, Jacob Bendixen og andre velstående Aabenraa-redere havde stiftet i 1839 til understøttelse af "trængende søfolk og personer, der har sejlet, samt deres familier" ${ }^{60}$ De gamle kaptajner vidste, at når det gik op, kunne det også gå ned. Det havde Caroline Bendixen så sandelig mærket, og i 1894 flyttede hun ind hos datteren Marie, som var blevet søster i brødremenigheden i Christiansfeld. Der døde hun ved middagstid den 16. marts 1902 efter et langt liv, der var gået op og ned med hendes svigerfader Jacob Bendixens rederi. ${ }^{61}$ 


\section{KILDER}

\section{Utrykte kilder:}

Københavns Stadsarkiv:

Borgerskabsprotokol 1809

Museum Sønderjylland - Kulturhistorie Aabenraa:

Marie Bendixens erindringer, kopi i Museumssag nr. 65

Brevveksling mellem Jacob Bendixen og Peter Wilhelm Lund, kopier i Museumssag nr. 37

MS - Museet for Søfart:

Kartotekskort over diverse skibe og kaptajner.

Rigsarkivet Aabenraa (RAÅ):

Aabenraa Købstad nr. 165d: Skibslister 1801-1818.

Folketællinger for Løjt Sogn 1835 og 1845.

Aabenraa amtsret: Grundbog for Stollig.

\section{LITTERATUR}

Hans Bruhns erindringer, Lildholdt, Claus og Karen Harder (red.), Aabenraa 2008.

"Hans Bruhns erindringer - et supplement", Mikkel Leth Jespersen (udg.): Historier fra Bybakken, 2014, s. 56-65.

Hansen, Hans Schultz: Hjemmetyskheden i Nordslesvig 1840-1867 - den slesvig-hol-
Notet Nordslesvig 1840-1867 - den slesvig-hol-
stenske bevxgelse, 2 bd. Aabenraa 2005.

Holdt, Jes M.: Gårde og Slxgter i Løjt sogn, Aabenraa 1982.
Aabes Slxgter i Løjt sogn, Aabenraa 1982

Holm-Petersen, F.: Under sejl i fjernøstlige farvande, Norderstedt 197

Holten, Birgitte og Michael Sterll: P.W. Lund og knokkelhulerne $i$ Lagoa Santa, København 2010.

Japsen, Gottlieb: "Åbenrå bys økonomiske historie 1850-64", Sønderiyske Årbøger 1935 og 1943.

Japsen, Gottlieb: Den nationale udvikling Åbenrå 1800-1850, Tonder 1961.

Jespersen, Mikkel Leth: „Apenrade-Hamburg-Rio de Janeiro. Mit Kolonisten und Soldaten über den Atlantik in den 1820er Jahren", in: Aus der Mitte des Landes. Klaus-Joachim Lorenzen-Schmidt
Christiansfeld præstearkiv: Fødte 18961924, konfirmerede, viede og døde 1896-1923, folio 186 (nr. 1574)

Aabenraa præstearkiv: Kirkebog 1887.

Privatarkiver, Søren Møller: Erindringer, hæfte 7.

Retsbetjentarkiver, Rise og Sønder Rangstrup herreder nr. 977-978: Skyld- og strup herreder $\mathrm{n}$.
panteprotokol I.

Rigsarkivet København (RAK):

Generaltoldkammer- og Kommercekollegiet, Handels- og Konsulatkontoret, nr 2983: Konsulatsrapporter m.m., Brasilien, Rio de Janeiro 1818-1830.

Udenrigsministeriet, Departement for Handel og Konsulatssager: Indkomn skibslister fra konsulaterne 1848-1864.

\section{Trykte kilder:}

Freja

zum 65. Geburtstag, Detlev Kraack og Martin Rheinheimer (red.), Neumünster/Hamburg 2013a, s. 275-290. Jespersen, Mikkel Leth: Kaptajner og kolonier. Sejlskibstidens oversøiske Aabenraa-
søfart, Aabenraa 2014. Kamphövener, Morten: Borgerskaber i Åbenrå 1686-1867, bd. I-II, Aabenraa 1974.

Kier, H.F.: "Rulle over Linieskibet PRINDS CHRISTIAN FREDERIKs Besætning under Kampen ved Sjællands Odde den 22. marts 1808", Tidsskrift for Søvxsen, 1958, s. 130-176.

Kirkebladet for Løjt Sogn, nr. 2 - februarmarts 1981 - 2. årg.

Larsen, Rolf: "Jørgen Bruhn - matadore fra Strågå̊rd". Det gamle Løjt IV, 1981, s. 104-143.

Larsen, Rolf: Hvorhen? Aabenraa-skibenes sejlads på verdenshavene, Aabenraa 2015.

Lassen, Hans Friedrich: Aabenraa Sømandskasse af 1839, Aabenraa 1983.

Løjt Sogns Historie, Hans H. Worsøe (red.) Aabenraa 1988.
Mercantil-Calender for det danske Monarchie 1858.

Mørkegaard, Ole m.fl.: "Jørgen Bruhn, søfart og søfolk fra Åbenrå 1781-1857", Nordslesvigske Museer, nr. 9, 1982, s. 133-167.

Mørkegaard, Ole: Søen, slagten og hjemstavnen. En undersøgelse af livsformer på åben råegnen 1700-1900, København 1993.

Nielsen, Erik Møller: Fra Klamp til Konstruktion. Fra håndvark til ingeniørkunst Aabenraa's sejlskibsbyggeri ca. 1800-1880 Aabenraa 2000.

Rasmussen, Carsten Porskrog: "Løjt - et maritimt miljø", i: Søfart selvfølgelig!

\section{NOTER}

1 Om Jørgen Bruhn se først og fremmest Larsen 1981 og Mørkegaard m.fl. 1982

2 Rasmussen 2012.

3 Løjt Sogns Historie, s. 171-173.

4 Kamphövener 1974 bd. I, s. 65 og 121 bd. II, s. 6 .

5 Løjt Sogns Historie, s. 107

6 RAÅ, Aabenraa Købstad nr. 165d.

7 Københavns Stadsarkiv, Borgerskabsprotokol 1809, s. 161.

Åbenrå Bys Historie, bd. 2, s. 141f.

9 Japsen 1961, s. 166; Mørkegaard 1993, s. 12

10 www.navalhistory.dk/danish/Historien/1801_1814/PCF_SjaellandsOdde1808.htm

11 Kier 1958, s. 130-176.

12 Schlaikier og Michelsen 1929, s. 174. Se også Hans Bruhns erindringer, side 35. også Hans Bruhns erin

13 Freja d. 4 . juli 1863.

www.skippere.dk/folder/index. php?site $=$ action 1

15 www.skippere.dk

6 Holdt 1982, s. 168f

17 Oplysningerne i dette afsnit stamme fra kartotekskort på arkivet ved M/S Museet for Søfart.

18 Kamphövener 1974, II, s. 6.

19 RAÅ, Retsbetjentarkiver, Rise og Sønder Rangstrup herreder nr. 977-978, Skyld- og panteprotokol Bd. 1, s. 763.

20 RAK, Generaltoldkammer- og Kommercekollegiet, Handels- og Konsulatkontoret nr. 2983

21 Se f.eks. Hans Bruhns erindringer, s. 50.
Festskrift $i$ anledning af Aabenraa Museums 125-års jubilaum, Mikkel Leth Jespersen (red.), Aabenraa 2012, s. 29-67. Aikier, Hans og Mads Michelsen: Aabenraa Søfarts Historie, Aabenraa 1929. Schäffer, Georg Antoine: Brasilien als Unabhängiges Reich in Historischer, Mercantilischer und Politischer Beziehungen, Geschildert vom Ritter von Schäffer Dr. Major der Brasilischen Ehrengarde etc. etc. etc., Altona 1824.

Abenrå Bys Historie, 3 bind, Aabenraa 196174.

22 Schäffer 1824, s. 403.

23 Jespersen 2013

24 Hans Bruhns erindringer, s. 107.

25 RAK, Generaltoldkammer- og Kommercekollegiet, Handels- og Konsulatkontoret, nr. 2983.

26 Hans Bruhns erindringer, s. 115.

27 Schlaikier og Michelsen 1929, s. 91.

28 Hans Bruhns erindringer, s. 113.

29 Schlaikier og Michelsen 1929, s. 90-91

30 Hans Bruhns erindringer, s. 50 .

31 Ibid. s. 108.

32 Ibid. s. 8.

33 Kamphövener 1974, II, s. 208.

34 "Hans Bruhns erindringer - et supplement", s. 64-65. Hans Bruhns erindringer s. 63 og 65 .

35 Kamphövener 1974, I, s. 208, II, s. 41

36 Holdt 1982, s. 139.

37 Holten og Sterll 2010, s. 70

38 Aabenraa Museum, Museumssag nr. 37, kopier efter originaler på Det Kongelige Bibliotek i København, P.W.
Lunds kopibog, HåndskriftssamlinLunds kopibog, Håndskriftssan kgl. samling nr. 32614.

39 Hen, ny kgl. samling nr.

40 Aabenraa Museum, BK-sag 65, Marie Bendixens erindringer, kopi.

41 Det gamle Løjt, nr. 7, s. 133.

42 Ibid. s. 139.

43 Hansen 2005, bd. I s. 465

44 Japsen 1961, s. 166.

45 Hansen 2005, bd. I, s. 310. Ibid s. 196

46 Ibid. s. 465.

47 Ibid. s. 454. 
48 Hans Bruhns erindringer, s. 57.

49 Holm-Petersen 1975, s. 119.

50 Hans Bruhns erindringer, s. 61.

51 Kirkebladet for Løjt Sogn, nr. 2 - februarmarts $1981-2$. årg., s. 2 .

52 Japsen 1935, s. 65f.

53 RAK, Udenrigsministeriet, Departement for Handel og Konsulatssager 1848-1903, Indkomne skibslister fra Konsulaterne 1848-1864.

54 Holm-Petersen 1975, s. 82

55 Ibid.

56 Holm-Petersen 1975, s. 81

57 Mørkegaard 1993, s. 116

58 Japsen 1935, s. 80f

59 RÅ̊, Privatarkiver, Søren Møllers erindringer, hæfte 7, s. 3.

60 Lassen 1983.

61 RAÅ, Christiansfeld præstearkiv, kirkebøger fødte 1896-1924, konfirmerede viede og døde 1896-1923, Fol 186 (nt. 1574): Kirkebogens beskrivelse af hen24. februar 1818 på det kongelige slo i Odense [som fejlagtigt kaldes Amalienborg] som ældste datter af overhustru Marie, født Bang. I 1845 [rigtig 1841] blev hun gift med skibskaptajn Bendix Georg Bendixen fra Stollig ved Aabenraa. I 1860 blev hans førhen rige Bruhn og Bendixens bankerot [det var kun Bendixen, der gik ned]. Manden blev ramt af fortvivlelse og slog sig pa flasken, og i 1894 kom hun som enke Som det fremgår af korrektionerne i de i beskrivelsen, men teksten formidle tydeligt de udsving, der havde præo Bendixen-dynastiets tilværelse præget endte med at koste Caroline og som des liv er kortfattet: Hun var født den hofjægermester von Warner og denne familie forarmet på grund af rederiet til brødremenigheden i Christiansfeld. skarpe parenteser, var der en række fel

\section{Zusammenfassung}

Im Laufe seines langen Lebens als Kapitän und Schiffsreeder schuf Jacob Bendixen aus Stollig auf Loit nahe Apenrade eine der größten Reedereien Dänemarks. Er war einer der ersten dänischen Kapitäne, die in den $1820^{\prime}$ ern Rio de Janeiro besegelten, danach ging er in seiner Heimat an Land und ließ am Hafen in Apenrade das eine große Schiff nach dem anderen bauen. Beobachter aus dieser Zeit beschreiben ihn als einen sympathischen Mann, dem es leicht fiel, freundschaftliche Beziehungen zu den Leuten in dem verhältnismäßig rauen Seefahrerklima zu erlangen. Er war der Schwager des größten Apenrade-Matadors aller Zeiten, Jørgen Bruhn, zu dem er sein Leben lang nahe geschäftsmäßige und persönliche Beziehungen hatte. Jørgen Bruhn starb 1858. Zur gleichen Zeit wurde die Reederei von Jacob Bendixen durch Fehlinvestitionen ruiniert, was für die Familie schwerwiegende Folgen hatte. Er starb als armer Mann, nur mit Mühe und Not gelang es einem seiner Söhne den Hof Stolliggaard weiter zu betreiben. Zwei der Kapitänssöhne mussten ihre Laufbahn zur See aufgeben, einer von ihnen endete seine Tage verarmt und alkoholisiert im Arbeitshaus in Apenrade.

\section{Die nationale Pflicht für das Mutterland}

\author{
Det tyske mindretals økonomiske kollaboration \\ under den tyske besættelse af Danmark 1940-45. ${ }^{1}$
}

Af Sidsel Maria von Qualen

Den 9. april 1940 klokken 04.15 overskred den tyske værnemagt den dansktyske grænse, og den tyske besættelse af Danmark var efter få timer en realitet. Dagen var for store dele af det tyske mindretal i Nordslesvig en glædens dag, da man stadig nærede et stærkt håb om en grænserevision og derfor regnede med, at besættelsen ville bringe en sådan med sig. Mindretallet strømmede ud på gader og stræder i Nordslesvig for med jubelråb og nazihilsen at byde de tyske tropper velkommen som befriere. For at ønsket om en grænserevision kunne opfyldes, måtte mindretallet dog yde sin tørn for moderlandets store kamp, og kimen til det tyske mindretals kollaboration under besættelsen var dermed lagt.

\section{Indledning}

Den ypperste kollaboration, man som tysksindet kunne yde, var aktiv krigsdeltagelse. Dette gjorde en stor del af mindretallets unge mænd, men hvad kunne man ellers gøre for at tjene moderlandet? For en gruppe unge kvinder kom tjenesten til udfoldelse ved arbejdet som frontsygeplejesker, de såkaldte frontsøstre. ${ }^{2}$ De unge pigers ypperste opgave var dog, ligesom hos kvinderne i mindretallet og i Det Tredje Rige, rollen som moder. ${ }^{3}$ De voksne kvinder var organiserede i de såkaldte Frauenschaften. ${ }^{4}$ For mændene i hjemstavnen var det for en stor dels vedkommende de paramilitære organisationer Zeitfreiwilligendienst og Selbstschutz-korpset. Endnu en mulighed lå i den økonomiske hjælp i form af arbejde for den tyske værnemagt i Danmark. Også denne form for hjælp var mere eller mindre forventet, hvis ikke fra Det Tredje Riges side, så fra det tyske mindretals side, der aktivt gik ind og støttede op om det økonomiske samarbejde.

Mange af disse aktiviteter inden for kollaborationen er allerede vel undersøgte, derfor vil fokus i denne artikel være på det tyske mindretals økonomiske kollaboration, da dette endnu ikke er særlig godt undersøgt. På baggrund af dette er følgende problemstilling relevant: 